\title{
Chapter
}

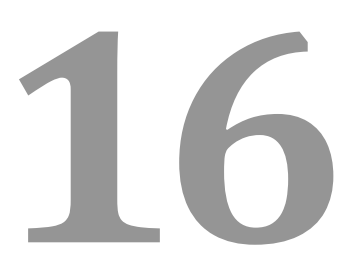

\section{NANOMATERIALS FOR CARTILAGE TISSUE ENGINEERING}

Loraine L.Y. Chiu ${ }^{1,2}$ and Stephen D. Waldman ${ }^{1,2 *}$

${ }^{1}$ Department of Chemical Engineering, Ryerson University, Toronto, Canada

2 Li Ka Shing Knowledge Institute, St. Michael's Hospital, Toronto, Canada 


\section{Contents}

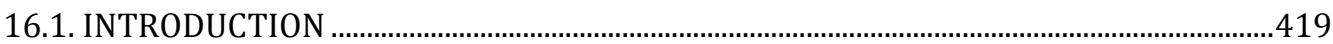

16.2. CARTILAGE TISSUE BIOLOGY......................................................................................420

16.2.1. Hyaline cartilage ................................................................................................. 421

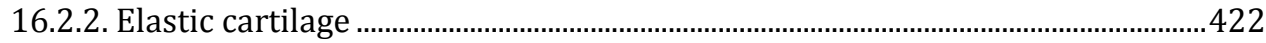

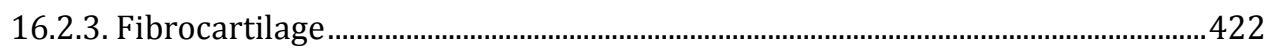

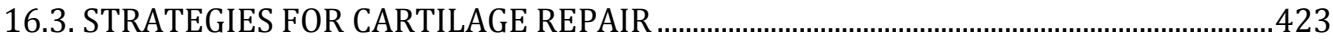

16.3.1. Current clinical strategies.....................................................................................423

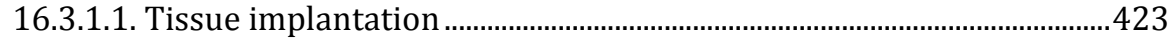

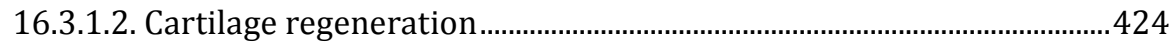

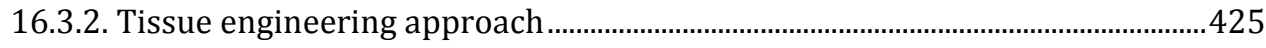

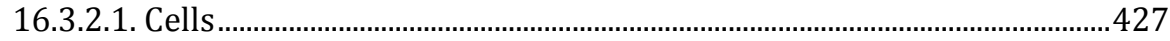

16.3.2.2. Biomaterials ................................................................................................ 428

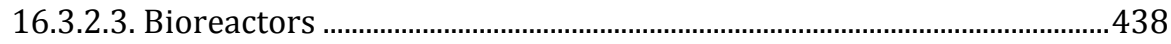

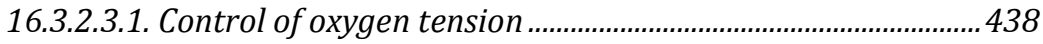

16.3.2.3.2. Transport of nutrients and metabolic waste ...........................438

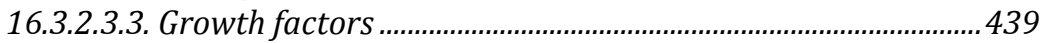

16.3.2.3.4. Application of mechanical forces................................................... 439

16.4. NANOMATERIALS FOR CARTILAGE TISSUE ENGINEERING .........................................440

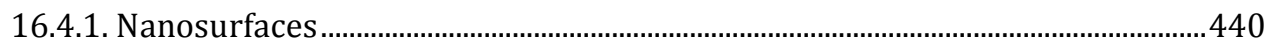

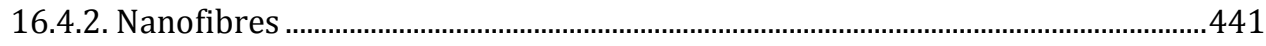

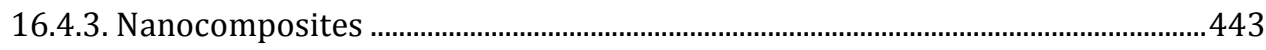

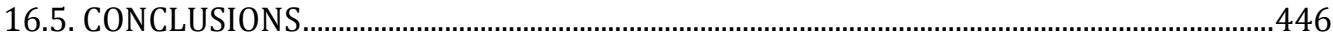

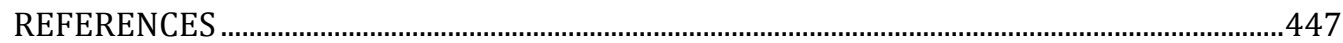




\subsection{INTRODUCTION}

Cartilage is a flexible connective tissue found in many areas of the body, such as within synovial joints (articular cartilage), the external ear (auricular cartilage), and the intervertebral disc (annulus fibrosis and nucleus pulposus). Classified into three distinct types (hyaline, elastic and fibrocartilage), this tissue is composed of specialized cells (chondrocytes) embedded in an extracellular matrix (ECM) primarily consisting of collagen fibres, proteoglycans, and elastic fibres (found only in elastic cartilage) - with the types and proportions of constituents unique for different cartilages. As all cartilages are avascular, cell growth and tissue regeneration is limited by the hypoxic environment, thus limiting the self-regenerative capacity of the damaged cartilage [1]. This motivates the search for tissue engineering strategies to repair cartilage defects caused by degenerative joint diseases, cancer or trauma.

Articular cartilage injuries are most common in the knee and can lead to premature arthritis if left untreated [2]. Repetitive stresses can cause irreparable damage in the joints, leading to the development of osteoarthritis. In osteoarthritis, the water content in the cartilage increases due to disruption of the matrix structure and increased permeability, thus leading to decreased stiffness and load bearing capacity. In the case of ear cartilage, external ear deformities are typically a result of both acquired and congenital defects. Acquired external ear deformities are caused by cancerous lesions that extend into the underlying cartilage and require amputation, as well as injuries due to animal bites and automobile accidents [3]. Congenital ear defects, such as external ear microtia and anotia, affect 129 out of $\sim 700,000$ newborns in Canada in 2006-2007 [4]. These deformities have significant psychosocial impact on individuals, thus motivating the need for surgical corrective procedures. Similar to the ear, the nose is highly susceptible to injury due to its exposed and unprotected position. Nasal fractures account for half of all facial fractures [5]. In addition, malformations of the nose and ear are found in congenital disorders that are characterized by facial malformations, such as Treacher Collins syndrome and Apert syndrome [6,7]. These malformations may also require cartilage reconstruction. Patients with congenital or benign stenosis of the trachea, resulting from trauma, inflammation or illness, require tracheal reconstruction [8]. Acquired tracheal stenosis occurs in 2-11\% of newborns [9]. In general, cancers in the nose, ear and trachea are increasing in numbers and often require resection, replacement and reconstruction.

Reconstructing or replacing the cartilage is challenging due to the complex geometry of cartilaginous structures in the facial region and the synovial joint surfaces as well as the required mechanical properties of the defect or repair site [1]. Advancements in tissue engineering have led to the development of 
biomaterials and culturing methodologies for cartilage regeneration. This chapter will focus on the use of nanomaterials for cartilage tissue engineering and regeneration.

\subsection{CARTILAGE TISSUE BIOLOGY}

Cartilage, a flexible connective tissue found in the nose, ear, trachea, ribs, joints and intervertebral discs (Figure 1), plays various roles in the human body depending on their type and location. These include providing structural support, maintaining shape and absorbing shock.

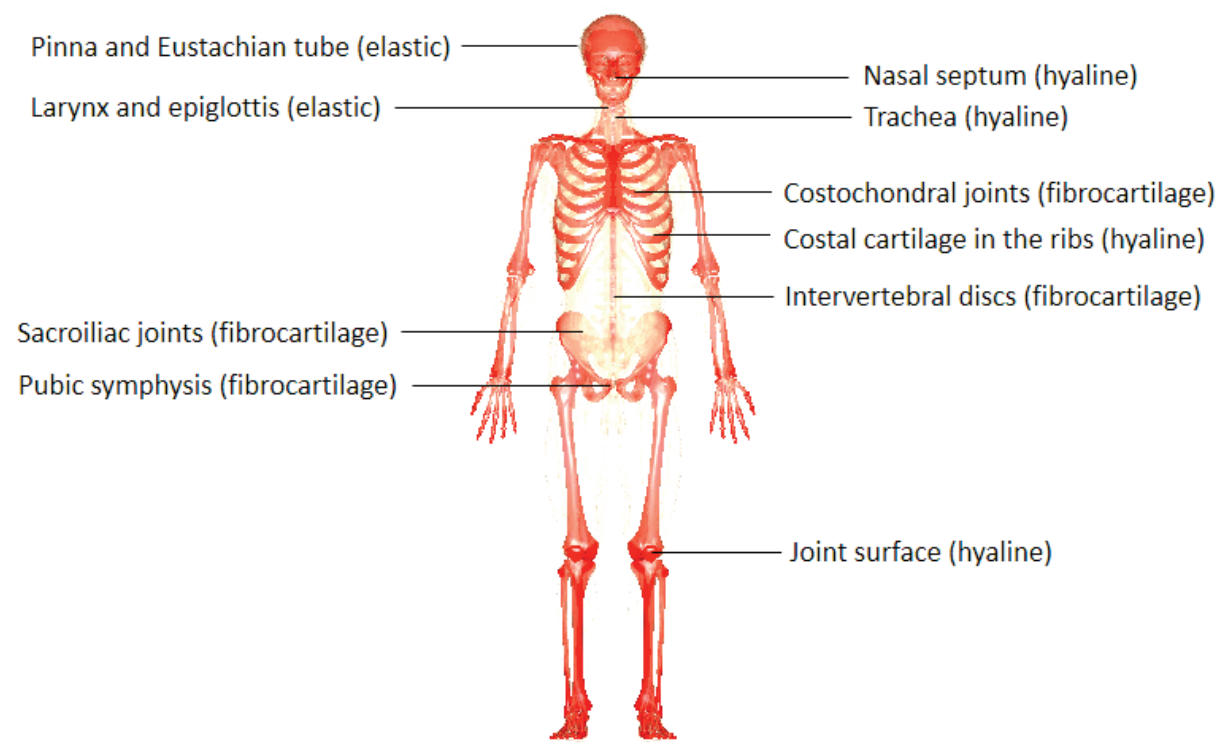

Figure 1. Cartilaginous regions in the human body

In the embryo, the cartilage is formed when mesenchyme cells start to aggregate to form a blastema at the $5^{\text {th }}$ week of gestation [2]. This is followed by the secretion of cartilaginous matrix by the cells of blastema, now called chondroblasts. The extracellular matrix produced pushes the cells apart, and the cells, now called chondrocytes, become encased in this specialized matrix. The mesenchymal tissue around the blastema develops into a membrane called the perichondrium.

As such, the cartilage is mainly composed of specialized cells called chondrocytes, which are situated in lacunae and secrete the extracellular 
matrix consisting of collagens, elastin, glycoproteins and proteoglycans. Cartilages of different types and functions vary in amounts of these extracellular matrix components. There are three types of cartilage - hyaline, elastic and fibrocartilage (Figure 2).
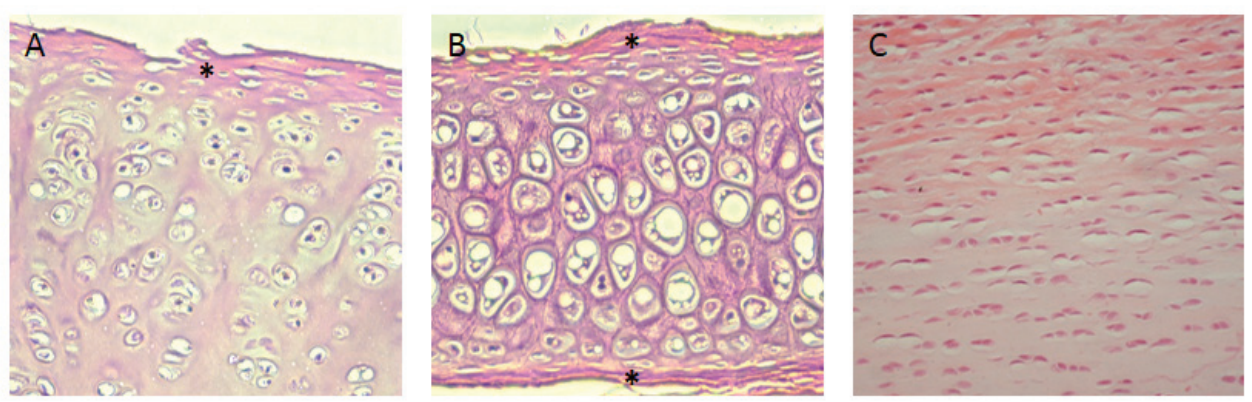

Figure 2. Three different types of cartilage. Hematoxylin and eosin staining of cross sections of (A) hyaline cartilage in the human nasal septum, (B) elastic cartilage in the rabbit ear, and $(C)$ fibrocartilage in the intervertebral disc.* indicates perichondrium surrounding the hyaline (A) and elastic cartilage tissues (B)

\subsubsection{Hyaline cartilage}

Hyaline cartilage is the predominant form of cartilage in the human body. It is present in the nasal septum, ribs, tracheal rings, and on the articular joint surfaces. The function of hyaline cartilage is primarily mechanical to provide resistance against bending, compression and impact [2]. This tissue is primarily composed of hydrated aggregates of proteoglycans within a collagen II meshwork. In most cases (with the exception of articular cartilage), hyaline cartilage is covered by an outer fibrous membrane called the perichondrium. Articular cartilage, however, has a specialized outer layer (adjacent to the synovial fluid) referred to as the superficial zone. This zone, which has some similarities to the perichondrium, provides a low-friction interface as well as contains anti-adhesive proteins (proteoglycan 4 or lubricin) to aid in joint motion [2].

Hyaline cartilage is generally composed of $1-5 \%$ chondrocytes by volume, 65-80\% wet weight of water, $10-20 \%$ wet weight of collagen, and 3-7 \% wet weight of proteoglycans [2]. The collagen network provides tensile strength, and this macrofibrilar framework is primarily consisted of type II collagen (90-95 \%). Other collagens in hyaline cartilage include collagen type VI, IX, X and XI, and have different functions including attaching chondrocytes to the matrix (collagen VI), contributing to tensile properties and inter-fibrillar connections (collagen IX), providing structural support and contributing to cartilage mineralization (collagen $\mathrm{X}$ in the case of articular cartilage), and 
nucleating fibril formation (collagen XI) [2]. Proteoglycans are proteins with glycosaminoglycan side chains. These hydrophilic macromolecules provide compressive strength to the tissue, and are responsible for maintaining the fluid and electrolyte balance [10]. They have negatively charged sulphate and carboxylate groups, in turn attracting positively charged molecules and increasing the total concentration of inorganic ions and osmolarity in the extracellular matrix. These molecules are produced and secreted by the chondrocytes in the matrix, and can be divided into two types: 1) large aggregating proteoglycan monomers or aggregans and 2) small proteoglycans such as biglycan, decorin, fibromodulin and lumican [11]. Glycosaminoglycans (GAGs), the subunits of proteoglycans, are disaccharide molecules. The two main types of GAGs are chondroitin sulphate and keratin sulphate. They are bound to the protein core through sugar bonds to form aggrecan, and can retain water.

Nutrients diffuse from the synovial fluid to the articular tissue. Joint loading creates cyclical pressures necessary for the normal function of hyaline cartilage and the transport of water and nutrients between the cartilage and synovial fluid.

\subsubsection{Elastic cartilage}

Elastic cartilage is found in the ear, particularly in the pinna and Eustachian tube, as well as in the larynx and epiglottis. Its role is to provide structural support and flexibility in these regions. While structurally similar to hyaline cartilage, the flexibility of elastic cartilage is due to its high content of elastic fibers (elastin and associated microfibrils), which are woven into a cartilaginous matrix also consisting primarily of collagen II and aggregating proteoglycans. Similar to most hyaline cartilages, elastic cartilage is surrounded by the perichondrium.

\subsubsection{Fibrocartilage}

Fibrocartilage is found in the intervertebral discs, costochondral joints, sacroiliac joints and pubic symphysis as well as specialized structures such as the meniscus. This tissue differs from hyaline and elastic cartilages, as it is characterized by an abundance of both collagen I and II fibers. Depending on the particular fibrocartilage, these fibers may have distinct orientations, such as in the annulus fibrous (of the intervertebral disc) and meniscus, which arrange into longitudinal and circumferential fibers [12]. This tissue can withstand high tensile stresses due to the arrangement of collagen fibers but generally does not perform well under compression [13]. 


\subsection{STRATEGIES FOR CARTILAGE REPAIR}

The goal of treating damaged or diseased cartilage, as with other damaged tissues, is to restore tissue structural integrity and function. Current clinical strategies include tissue implantation (Section 16.3.1.1.) and approaches to stimulate cartilage regeneration (Section 16.3.1.2.). In addition, a growing number of studies are performed to evaluate the use of engineered tissues to treat cartilage defects (Section 16.3.2.).

\subsubsection{Current clinical strategies}

For the repair of articular cartilage defects, the strategy used depends on the extent of damage and / or degeneration. Defects of the articular cartilage that do not penetrate to the subchondral bone cannot undergo intrinsic healing processes since the progenitors of the bone marrow space are not accessible. In contrast, defects that penetrate the subchondral bone have been shown to undergo intrinsic repair processes that usually result in a fibrocartilage tissue that possesses inferior properties compared to hyaline cartilage. Defects in joint cartilages are commonly treated with either implantation of tissues (Section 16.3.1.1.) or cartilage regeneration approaches (Section 16.3.1.2.).

Cartilaginous defects in the external ear, nose and trachea are commonly treated with surgical procedures, with or without the implantation of tissues or prosthetics (Section 16.3.1.1.). The surgical procedure may involve the resection of the damaged/diseased cartilage, which may be followed by anastomosis in the case of the trachea. While defects in facial cartilaginous features (i.e. ear and nose) may not cause pain as with defects in the joint region, the treatment of these defects can significantly improve the quality of life for patients. Besides correcting the appearance of these features, surgical treatment of the nasal cartilage defects may improve breathing problems. The need for clinical treatment of tracheal defects is clear as tracheal defects or abnormalities may cause severe breathing problems and eventually lead to premature death.

Different current clinical strategies for cartilage repair and reconstruction will be briefly described here. As this chapter focuses on nanomaterials used for cartilage tissue engineering, we refer readers to excellent reviews [2,14] for more details on these clinical approaches.

\subsubsection{Tissue implantation}

Tissue implantation is a widely used strategy for the repair and reconstruction of articular cartilage defects. One commonly used procedure is osteochondral transfer used for the repair of osteochondral defects $[2,15,16]$. This method involves the harvest of cylindrical osteochondral donor plugs from the low weight bearing areas within the knee joint. The defect site is first prepared followed by implantation of donor osteochondral plug(s) (one or more depending on the size of the defect) to fill the defect. This treatment needs to 
be limited to $1-4 \mathrm{~cm}^{2}$ so as to prevent excessive donor site morbidity [17]. While it was originally developed as an open procedure, it can now be done arthroscopically with current surgical instrumentation and techniques. However, this procedure remains to be technically difficult and can result in variable patient outcomes based on differences in the height of the defect cartilage and the surrounding native cartilage as well as the accumulation of fibrocartilage within the gaps regions between the transplanted plugs $[17,18]$. For the repair of chondral defects, other implantation treatment methods involve grafting strips of perichondrium [19] or periosteum [20-22] to the defect using fibrin glue. In the case of periosteal grafts, the problem of graft calcification can occur over time. However, periosteum is more available (than perichondrium) and is widely used for transplantation purposes. The periosteum is also of interest for cartilage repair as this tissue contains a population of chondrocyte precursor cells in its inner layer (referred to as the cambium) [14].

Approaches for reconstruction of the ear, nose and trachea include the surgical transplantation of autologous tissues, allografts, prosthetic materials, or a combination of these methods. One conventional method is to harvest autologous cartilage from the rib, which is subsequently shaped by the surgeon, for surgical replacement of the damaged tissue [23]. While this approach can be quite successful, this invasive procedure creates a donor site defect and may also require multiple revision surgeries. Importantly, the mechanical properties of the rib cartilage may not be suitable for reconstruction in all cases. Prostheses that may be used for reconstruction purposes are made from silicone or wax, but there have been increased reports of infections in patients.

While conventional treatment of tracheal disease can routinely be accomplished by a direct anastomosis [8], only half of the tracheal length for adult patients and one third for pediatric patients can be resected. Alternative approaches are then required for larger defects. Experimentally, tracheal conduits have been shaped from autografts such as bowel segments and jejunal flap with costal cartilage skeleton [24,25], allografts [26,27], prosthetic materials such as poly(dimethyl siloxane) (Silastic) covered with Dacron mesh at the ends for suturing purposes or a Marlex mesh reinforced with a Teflon spiral [28,29], or a combination such as combined jejunal tissue with a Dacron graft [30]. These replacements do not have the same properties of the native tissue and their implantation may result in inflammation and poor integration to the host tissue.

\subsubsection{Cartilage regeneration}

Cartilage regeneration techniques have primarily been explored for the repair of articular cartilage defects. Penetration of subchondral bone is the oldest and most commonly used method to induce cartilage regeneration through bone 
marrow stimulation [2]. It is useful for a full thickness chondral defect containing exposed subchondral bone. The principle of this method is to disrupt the subchondral blood vessels by penetrating the subchondral bone plate, in turn forming a fibrin clot on the defect site. When protected from loading, the fibrin clot recruits bone marrow mesenchymal stem cells, which proliferate and differentiate into chondrocyte-like cells. The most common of these approaches is microfracture. Microfracture is a simple and common first-line arthroscopic treatment for symptomatic chondral defects [2]. First described by Steadman et al. [31], this procedure involves the removal of all unstable cartilage within the defect site followed by the creation of fracture holes (using an arthroscopic awl) to penetrate the subchondral bone. As a result, the defect becomes filled with a fibrin clot, which allows the differentiation of pluripotent marrow cells. Spongialization is a more radical version of marrow stimulation which involves the complete excision of the subchondral bone at the defect site [32].

Another type of articular cartilage regeneration approach is cell based therapy. Specifically, autologous chondrocyte implantation (ACI) or matrix-induced autologous chondrocyte implantation (MACI) therapies have been used for the repair of articular, chondral defects. This procedure involves enzymatically isolating and propagating autologous articular chondrocytes (obtained from the low weight bearing regions in the joint) and then implanting these cells into the defect site as a cell suspension (ACI) or in combination with a matrix material (MACI) [14,33,34]. The implanted cells produce their own extracellular matrix to repair the damage site. Clinical studies showed promising results for this approach. Brittberg et al. [35] showed that 11 out of 15 biopsies from treated femoral condyle lesions had hyaline-like appearance, and the treatment was durable up to 11 years [36]. However, the success of this approach is controversial. Knutsen et al. [37] found ACI and microfracture to be comparable treatment methods after 5 years, while a more recent study by Saris et al. [38] showed that ACI resulted in better tissue regeneration in chondral defects than microfracture despite having comparable clinical scores. Long term studies need to be performed in order to evaluate the survival of the ACI tissue. A modified version of the ACI method involves the injection of bone marrow mesenchymal stem cells rather than chondrocytes [39].

\subsubsection{Tissue engineering approach}

As few of the current treatment methods described in Section 16.3.1. result in successful repair or regeneration of damaged cartilage, the development of new procedures are warranted. One popular research area is tissue engineering, which combines principles of cell biology, medicine and engineering to create tissue constructs that possess the morphological and functional properties of native tissue. Important features that need to be achieved for development of implantable engineered cartilaginous tissues include: the creation of large sized implants and attainment of appropriate 
mechanical properties, biochemical composition and cellular morphology. The classical tissue engineering approach is to seed isolated cells onto scaffolds and to cultivate the cell / scaffold constructs in a bioreactor (Figure 3) and / or in the presence of stimulatory factors. Thus far, engineered cartilage constructs have unsatisfactory mechanical properties and collagen contents much less than native tissue [40,41]. For example, the flexural modulus of engineered nasal constructs is typically less than half of that of the native nasal cartilage [40]. The proper stiffness is important for the engineered cartilaginous tissues to maintain their structure. Current developments in cartilage tissue engineering is focused on yielding engineered tissues that have improved structure and functionality.

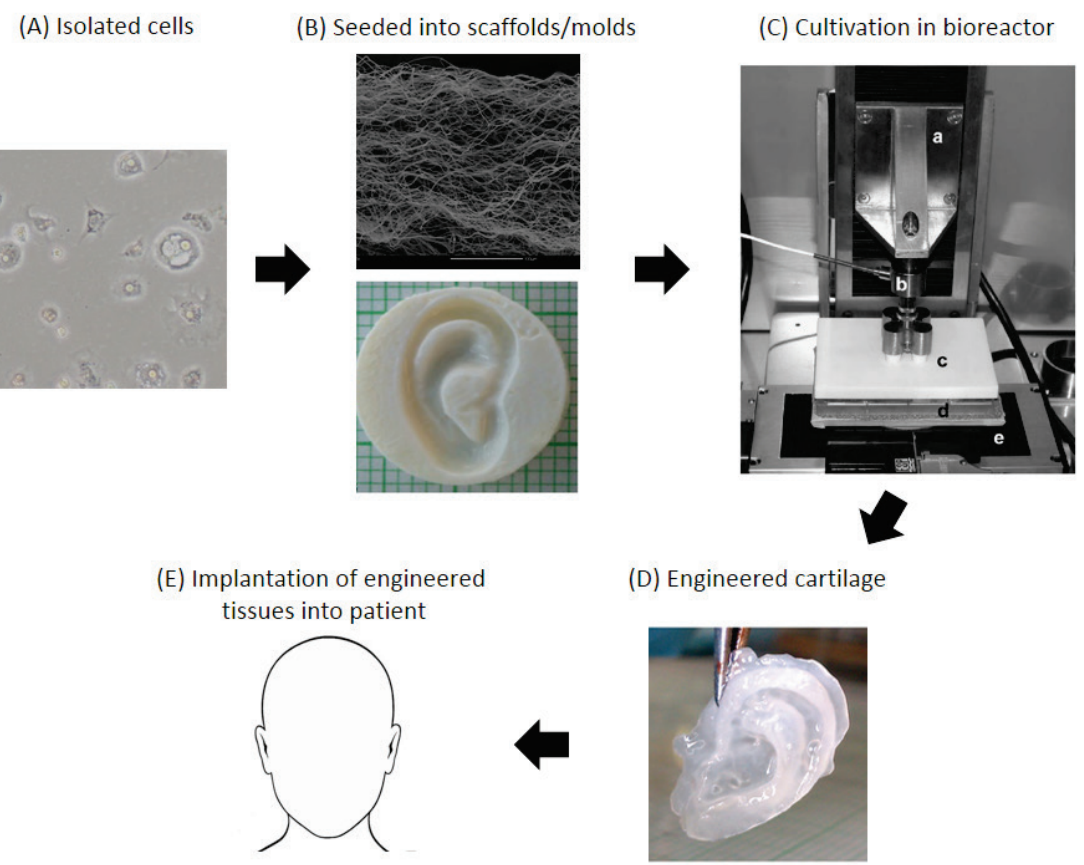

Figure 3. The classical tissue engineering approach. (A) Cells, commonly chondrocytes or mesenchymal stem cells, are first isolated from the patient's tissues by an enzymatic digestion. The image here shows microscopy image of rabbit ear chondrocytes. The cells are then seeded into (B) a scaffold [122] or a mold [99], or (C) directly into a bioreactor. A bioreactor may be just a static dish or more sophisticated systems that can provide shear stress and control oxygen tension. The image here shows a bioreactor that provides intermittent shear stimulation to engineered cartilage tissues [123]. (D) The constructs are grown until reaching desired properties that mimic the native tissue. The image here shows an engineered ear using a mold placed in a continuous flow bioreactor [99]. (E) The engineered tissues can potentially be implanted into the patient. 


\subsubsection{Cells}

Chondrocytes are specialized cells in the cartilage that synthesize and maintain the matrix structure [2]. They are spheroidal in shape and have no cell-to-cell contacts. These cells are sparsely arranged within the matrix and receive nutrition via diffusion through the matrix. They depend on an anaerobic metabolism and survive on low oxygen concentrations. Although they have high metabolic activity, the total activity is low due to a low cellular volume of the tissue. Chondrocytes are commonly used in cartilage tissue engineering because they are the cells resident in the native cartilage.

While full depth chondrocytes have been predominantly used for transplantation and tissue engineering, specific chondrocyte sub-populations can be used to improve the functional properties of tissue engineered cartilage. Waldman et al. [42] investigated the use of chondrocytes from different zones of the articular cartilage for tissue engineering, including full-thickness, mid-and-deep zone and deep zone chondrocytes. These different sub-populations were isolated and cultured on porous calcium phosphate substrates. While collagen synthesis was the highest with full-thickness chondrocytes, mid-and-deep zone chondrocytes yielded engineered tissues with improved mechanical properties and increased amount of proteoglycans. Dowthwaite et al. [43] isolated a chondrocyte sub-population from the superficial zone of the immature bovine articular cartilage. This sub-population has progenitor cell-like properties with high colony forming ability as well as high propagation capacity. Colony-derived populations of these progenitors could be engrafted into different connective tissue lineages.

The application of stem cell technology is gaining interest to be used for cartilage tissue engineering since stem cells have high proliferative capacity and multi-lineage differentiation potential. The precursor of chondrocytes is mesenchymal stem cells (MSCs). Traditionally, the source of these stem cells is the bone marrow. Various studies have been conducted to promote the propagation and differentiation of MSCs, using growth factors, biomaterials and different stimulation methods such as the application of mechanical forces or the control of oxygen tension in bioreactors. Adult bone marrow derived MSCs can give rise to chondrocytes when cultured in a 3D environment in the presence of transforming growth factor- $\beta$ (TGF- $\beta$ ) family of growth factors [44]. In particular, TGF- $\beta 1$ has been shown to induce in vitro chondrogenesis of rabbit bone marrow derived MSCs [45]. Human bone marrow derived MSCs could also undergo chondrogenic differentiation under appropriate conditions $[46,47]$. These cells also increase osteochondral differentiation when implanted in vivo [48,49].

Recently, new sources of mesenchymal stem cells have been discovered, including adipose tissue, blood and the synovium. Mesenchymal stem cells isolated from human synovial membranes were shown to be capable of expansion into larger numbers and induction of chondrogenesis in vitro [50]. 
In addition, it has been reported that in vitro expanded human articular chondrocytes have characteristics similar to a progenitor cell, although it is not yet known the specific type of progenitor cells [51]. In another study, a MSC population was found in normal and osteoarthritic human articular cartilage [52]. There is a higher number of progenitor cells in osteoarthritic cartilage compared to normal cartilage. It is unclear whether this is due to the recruitment of these cells from the surrounding synovium or the conversion of MSCs in the defect into an immature phenotype.

Multiple cell types may be co-cultured in cartilage tissue engineering to mimic the complex composition and structure of each native cartilage tissue. While the cartilage is composed of a single cell type (chondrocytes), the adjacent cells play an important role in the functionality of the cartilaginous organs. For example, the auricular cartilage (elastic cartilage) is composed of a central chondrogenic layer sandwiched between two perichondrial layers. Giardini-Rosa et al. [53] developed a new method of engineering auricular cartilage constructs with structure similar to the native tissue, consisting of the cartilage zone with a single perichondrial layer on top. The lumens of trachea are lined with epithelial cells, and the lack of epithelial lining has been linked to tracheal stenosis in tissue-engineered trachea [41]. The co-culture of perichondrial and epithelial cells with chondrocytes may improve the functionality of engineered auricular and tracheal tissues.

\subsubsection{Biomaterials}

Scaffolds are important to provide a three-dimensional structure for supporting the synthesis of cartilage-specific extracellular matrix proteins, depending on the type (hyaline, elastic, fibrocartilage) of cartilage to be developed. Numerous scaffolds have been investigated for cartilage tissue engineering, including both natural and synthetic biomaterials. There are also different methodologies for the fabrication of scaffolds used in cartilage tissue engineering. Important factors need to be considered in scaffold development, such as biocompatibility, mechanical stability, pore size and porosity, shape, degradation, and ability to integrate with native tissue $[1,14]$.

Natural biomaterials for cartilage tissue engineering include alginate, chitosan, collagen, fibrin and hyaluronan (Table 1). Alginate is commonly used to encapsulate and culture chondrocytes or to study the chondrogenic differentiation of cultivated mesenchymal stem cells. Chia et al. [54] showed that chondrocytes encapsulated in alginate produced higher levels of glycosaminoglycans compared to cells in monolayers, which dedifferentiate into a fibroblast-like phenotype. However, the alginate does not promote redifferentiation. Lin etal. [55] similarly showed that primary porcine chondrocytes could maintain their differentiated state for 4 weeks of culture in porous three-dimensional alginate scaffolds within a perfusion system. In another study, MSCs were encapsulated in alginate beads and treated with 
TGF- $\beta 3$ for 3,6 or 14 days, after which the cells were cultured without the growth factor for an additional 2 weeks [56]. Stimulation with TGF- $\beta 3$ within the first 3 days of cultivation appeared to be necessary for chondrogenesis. $\mathrm{Xu}$ et al. [57] developed a staging scheme for in vitro chondrogenic differentiation of human mesenchymal stem cells by growing the cells in three-dimensional alginate gels. The cells undergo four stages: 1) Stage 1 at days 0-6 expressing collagen I, VI, Sox 4 and BMP-2, 2) Stage 2 at days 6-12 expressing HAPLN1, collagen XI and Sox 9, 3) Stage 3 at days 12-18 expressing matrilin 3, Ihh, Homeobox 7, chondroadherin and WNT 11, and 4) Stage 4 at days 18-24 expressing aggrecan, collagen IX, II and X, osteocalcin, fibromodulin, PTHrP and alkaline phosphatase. Chondrocytes in alginate were also injected into mice in vivo [58]. Dobratz et al. [58] injected human nasal septal chondrocytes in sodium alginate subcutaneously on the back of mouse followed by injection with calcium chloride to crosslink the alginate. The engineered cartilage was harvested at different time points and most explants resembled the native cartilage in gross morphology. While many explants resembled native cartilage in histological morphology, there was presence of fibrous tissue areas in the engineered cartilage. When grown for more than 26 weeks, the engineered cartilage resembled native septal cartilage in terms of collagen content.

Table 1. Natural biomaterials used for cartilage tissue engineering

\begin{tabular}{|c|c|c|c|c|}
\hline Biomaterial & Methods & Cells Used & Significant Results & Ref. \\
\hline \multirow[t]{5}{*}{ Alginate } & $\begin{array}{c}\text { in vitro cell } \\
\text { encapsulation }\end{array}$ & $\begin{array}{l}\text { human nasal septal } \\
\text { chondrocytes }\end{array}$ & $\begin{array}{l}\text { higher level of } \\
\text { GAG compared to } \\
\text { monolayers }\end{array}$ & [54] \\
\hline & & $\begin{array}{c}\text { porcine } \\
\text { chondrocytes }\end{array}$ & $\begin{array}{l}\text { maintained } \\
\text { differentiated state } \\
\text { for } 4 \text { weeks }\end{array}$ & {$[55]$} \\
\hline & & human MSCs & $\begin{array}{l}\text { stimulation with } \\
\text { TGF- } \beta 3 \text { led to } \\
\text { chondrogenesis }\end{array}$ & [56] \\
\hline & & human MSCs & $\begin{array}{l}\text { identified } 4 \text { stages of } \\
\text { in vitro chondrogenic } \\
\text { differentiation }\end{array}$ & [57] \\
\hline & $\begin{array}{l}\text { in vivo cell injection } \\
\text { into mice } \\
\text { subcutaneously }\end{array}$ & $\begin{array}{l}\text { human nasal septal } \\
\text { chondrocytes }\end{array}$ & $\begin{array}{l}\text { injection into mice led to } \\
\text { growth of native-like } \\
\text { cartilage }\end{array}$ & [58] \\
\hline Chitosan & $\begin{array}{c}\text { seeding of scaffolds } \\
\text { with different fiber } \\
\text { sizes }\end{array}$ & $\begin{array}{c}\text { porcine } \\
\text { chondrocytes }\end{array}$ & $\begin{array}{l}\text { supported matrix } \\
\text { production }\end{array}$ & [59] \\
\hline
\end{tabular}




\begin{tabular}{|c|c|c|c|c|}
\hline Biomaterial & Methods & Cells Used & Significant Results & Ref. \\
\hline & $\begin{array}{l}\text { seeding of sponges } \\
\text { with different pore } \\
\text { sizes, cultivated in } \\
\text { a rotating } \\
\text { bioreactor }\end{array}$ & $\begin{array}{c}\text { porcine } \\
\text { chondrocytes }\end{array}$ & $\begin{array}{l}\text { control polyglycolic acid } \\
\text { (PGA) meshes led to } \\
\text { DNA and GAG contents } \\
\text { more similar to native } \\
\text { cartilage }\end{array}$ & [60] \\
\hline & $\begin{array}{l}\text { loaded chitosan } \\
\text { microspheres with } \\
\text { TGF- } \beta 1 \text {, } \\
\text { incorporated } \\
\text { microspheres into } \\
\text { chitosan scaffolds } \\
\text { and seeded cells }\end{array}$ & rabbit chondrocytes & $\begin{array}{c}\text { release of TGF- } \beta 1 \text { in a } \\
\text { multiphasic manner; } \\
\text { stimulated cell } \\
\text { proliferation and } \\
\text { collagen II synthesis }\end{array}$ & {$[61]$} \\
\hline & $\begin{array}{l}\text { loaded BMP-6 onto } \\
\text { scaffolds and } \\
\text { seeded cells }\end{array}$ & $\begin{array}{l}\text { mouse MC3T3-E1 } \\
\text { cells }\end{array}$ & $\begin{array}{c}\text { increased GAG, collagen } \\
\text { II and DNA }\end{array}$ & [84] \\
\hline \multirow[t]{3}{*}{ Collagen } & $\begin{array}{l}\text { seeding of porous } \\
\text { sponges }\end{array}$ & $\begin{array}{l}\text { bovine articular } \\
\text { chondrocytes }\end{array}$ & $\begin{array}{l}\text { chondrogenesis with } \\
\text { serum or with } \\
\text { Nutridoma as serum } \\
\text { replacement }\end{array}$ & [62] \\
\hline & $\begin{array}{l}\text { encapsulation of } \\
\text { cells in hydrogels } \\
\text { and implantation } \\
\text { into rabbits } \\
\text { subcutaneously }\end{array}$ & rabbit BMSCs & $\begin{array}{l}\text { cells showed } \\
\text { characteristics of } \\
\text { chondrocytes }\end{array}$ & [63] \\
\hline & $\begin{array}{l}\text { seeding of hybrid } \\
\text { scaffolds made of } \\
\text { collagen I and PLGA } \\
\text { and implantation } \\
\text { into mice } \\
\text { subcutaneously }\end{array}$ & bovine chondrocytes & $\begin{array}{l}\text { deposition of } \\
\text { cartilaginous } \\
\text { extracellular matrix }\end{array}$ & [64] \\
\hline Fibrin & $\begin{array}{c}\text { delivery of } \\
\text { chondrocytes to } \\
\text { treat human } \\
\text { articular cartilage } \\
\text { defects }\end{array}$ & $\begin{array}{l}\text { autologous } \\
\text { chondrocytes }\end{array}$ & $\begin{array}{c}\text { grafts filled and } \\
\text { integrated in patients' } \\
\text { defects after } 24 \text { months }\end{array}$ & [65] \\
\hline Hyaluronan & $\begin{array}{l}\text { cultured autologous } \\
\text { chondrocytes on } \\
\text { scaffolds and } \\
\text { implanted } \\
\text { constructs into } \\
\text { human cartilage } \\
\text { defects }\end{array}$ & $\begin{array}{l}\text { autologous } \\
\text { chondrocytes }\end{array}$ & $\begin{array}{l}\text { hyaline-like cartilage } \\
\text { formed in the grafted } \\
\text { site after } 17.5 \text { months }\end{array}$ & [66] \\
\hline
\end{tabular}




\begin{tabular}{|c|c|c|c|c|}
\hline Biomaterial & Methods & Cells Used & Significant Results & Ref. \\
\hline & $\begin{array}{l}\text { seeding of MSCs in } \\
\text { photocrosslinked } \\
\text { hydrogels; } \\
\text { in vitro culture and } \\
\text { in vivo } \\
\text { subcutaneous } \\
\text { culture in mice }\end{array}$ & human MSCs & $\begin{array}{l}\text { higher expression of } \\
\text { cartilage specific } \\
\text { markers than in PEG } \\
\text { hydrogels; } \\
\text { incorporation of } \\
\text { TGF- } \beta 3 \text { increased } \\
\text { collagen II, aggrecan, } \\
\text { Sox } 9 \text { in vivo }\end{array}$ & [67] \\
\hline
\end{tabular}

Chitosan is another natural material used for cartilage tissue engineering due to its similarity with glycosaminoglycans present in the native cartilage. Ragetly et al. [59] fabricated chitosan nonwoven scaffolds with fibers of different sizes $(4,13$ and $22 \mu \mathrm{m}$ in width), using a replica molding technique. These scaffolds were seeded with porcine chondrocytes and supported matrix production (GAG and collagen II) per chondrocyte compared to the control polyglycolic acid mesh, especially those with smaller fibers. The increased matrix production is likely due to the chemical composition of the scaffolds. In another study, porcine chondrocytes were cultured on chitosan sponges with different pore sizes $(10,10-50,70-120 \mu \mathrm{m}$ in diameter) or polyglycolic acid mesh for 28 days in a rotating bioreactor [60]. While the proliferation and metabolic activity of chondrocytes improved with increasing pore size of chitosan scaffolds, polyglycolic acid meshes produced tissue constructs with DNA and GAG contents more closely resembling that of the native cartilage. Chitosan is a common biomaterial used to deliver bioactive molecules to cultured chondrocytes [61].

Yates et al. [62] cultured bovine articular chondrocytes on three-dimensional porous collagen sponges in both standard and serum-free conditions. Generally, the collagen sponges provided a favorable environment for chondrogenesis. At 4 weeks, chondrogenesis by cells cultured with Nutridoma as a serum replacement was equivalent or better compared to cells cultured with serum, while cells cultured with insulin-transferrin-selenium (ITS) serum replacement showed poor chondrogenesis due to decreased cell survival. Chondrogenesis of mesenchymal stem cells can also be induced by providing a chondrogenic environment. For example, bone marrow mesenchymal cells were encapsulated in a collagen hydrogel which was then placed in diffusion chambers that allow permeation of body fluids and infiltration of host cells [63]. These chambers with cell-encapsulated hydrogels were implanted subcutaneously in the back of rabbits. At 8 weeks, the mesenchymal cells grown in the hydrogels showed characteristics of chondrocytes. Tissues grown in collagen-alginate hydrogels expressed less collagen II than those in collagen-based hydrogels. In another study, bovine chondrocytes were cultured on hybrid scaffolds made of collagen I and PLGA, which were then 
transplanted subcutaneously into mice [64]. The PLGA mesh acts as a skeleton and the collagen microsponges aided cell attachment and growth. Three hybrid scaffolds were investigated: (i) PLGA mesh with collagen microsponge formed in its interstices, (ii) PLGA mesh with collagen microsponge formed on one side, and (iii) PLGA mesh with collagen sponge formed on both sides. Transplants made of all three scaffolds led to deposition of cartilaginous extracellular matrix. The scaffolds made of PLGA mesh with collagen microsponge on one side or both sides showed increased GAG, collagen II and aggrecan compared to the scaffolds with PLGA mesh with collagen microsponge in the interstices.

Fibrin has been used as a biomaterial to deliver autologous chondrocytes to treat full thickness articular cartilage defects [65]. At 24 months post-surgery, 29 out of 30 patients showed fair to excellent results, with only one poor result. These grafts had good fill and integration in the patients' defects.

Clinical trials using Hyalograft $\mathrm{C}^{\mathrm{TM}}$, a hyaluronan-based scaffold, have been performed to treat articular cartilage defects [66]. Pavesio et al. [66] cultured expanded autologous chondrocytes on hyaluronan scaffolds and implanted the constructs into the cartilage defects in patients. Most grafted sites showed hyaline-like cartilage after an average follow-up time from implantation of 17.5 months. MSCs can interact with hyaluronic acid through their cell surface receptors (e.g. CD44) as hyaluronic acid is a native component of cartilage. As such, hyaluronic acid hydrogels could play a role in the differentiation of these stem cells. In both in vitro and in vivo cultures, MSCs seeded in photocrosslinked hyaluronic acid hydrogels showed chondrogenesis and expressed higher levels of cartilage specific markers compared to using PEG hydrogels [67]. In vivo, the addition of TGF- $\beta 3$ enhanced the expression of collagen type II, aggrecan and Sox9.

Natural scaffolds can have problems with immunogenic incompatibility and batch inconsistency [14]. In contrast, synthetic scaffold properties can typically be better controlled. Synthetic biomaterials for cartilage tissue engineering include polyhydroxyacids, such as polylactide (PLA), polyglycolide (PGA), poly( $\varepsilon$-caprolactone) (PCL) and their copolymers, and polyethylene glycol (PEG) hydrogels (Table 2). 
Table 2. Synthetic and composite biomaterials used for cartilage tissue engineering

\begin{tabular}{ccccc}
\hline Biomaterial & Methods & Cells Used & Significant Results & Ref. \\
\hline $\begin{array}{c}\text { poly(lactic- } \text { co- }^{-} \\
\text {glycolic acid) }\end{array}$ & seeding of & rat & formation of & scaffolds and \\
(PLGA) & chondrocytes & neocartilage after & \\
& implantation & & 4 months & \\
& into mice & & & \\
& subcutaneously & & &
\end{tabular}

$\begin{array}{cc}\text { seeding of } & \text { rabbit } \\ \text { microspheres } & \text { chondrocytes } \\ \text { and injection } & \\ \text { into mice } & \\ \text { subcutaneously } & \end{array}$

seeding of MSCs rabbit MSCs onto scaffolds and transplantation into rabbit knee defects
seeding of cells in fibrin onto scaffolds

rabbit
articular
chondrocytes

good adhesion to microsphere surface; formation of solid white cartilaginous tissues in implantation site after 4 weeks

$$
\begin{aligned}
& \text { defects filled with } \\
& \text { smooth white } \\
& \text { hyaline-like tissues } \\
& \text { after } 12 \text { weeks }
\end{aligned}
$$

fibrin aided cell attachment and distribution; led to more GAG production compared to PLGA only control

$\begin{array}{cc}\begin{array}{c}\text { seeding of cells } \\ \text { onto scaffolds } \\ \text { with }\end{array} & \begin{array}{c}\text { bovine } \\ \text { articular } \\ \text { chondrocytes }\end{array} \\ \begin{array}{c}\text { immobilized } \\ \text { hyaluronic acid }\end{array} & \\ \text { seeding of cells } \\ \text { onto hyaluronic } \\ \text { acid modified } \\ \text { scaffolds }\end{array} \begin{gathered}\text { human } \\ \text { derived stem } \\ \text { cells }\end{gathered}$
attachment as well as synthesis of GAG and collagen compared to PLGA only control higher expression of chondrogenic marker genes and increased production of GAG and collagen II compared to

PLGA only control 


\begin{tabular}{|c|c|c|c|c|}
\hline Biomaterial & Methods & Cells Used & Significant Results & Ref. \\
\hline $\begin{array}{l}\text { polyglycolic acid } \\
\text { (PGA) }\end{array}$ & $\begin{array}{c}\text { seeding of } \\
\text { scaffolds and } \\
\text { comparison to } \\
\text { PLGA scaffolds }\end{array}$ & $\begin{array}{c}\text { human } \\
\text { chondrocytes }\end{array}$ & $\begin{array}{l}\text { expression of aggrecan } \\
\text { and collagen II higher } \\
\text { in PGA scaffolds }\end{array}$ & {$[72]$} \\
\hline \multirow[t]{3}{*}{$\begin{array}{c}\text { polycaprolactone } \\
\text { (PCL) }\end{array}$} & $\begin{array}{l}\text { in vitro culture } \\
\text { in porous } \\
\text { scaffolds }\end{array}$ & human MSCs & $\begin{array}{l}\text { cell-scaffold constructs } \\
\text { became hard after } \\
3 \text { weeks; higher DNA } \\
\text { and GAG contents when } \\
\text { scaffolds were treated } \\
\text { with Pluronic F127 } \\
\text { and/or collagen }\end{array}$ & [73] \\
\hline & $\begin{array}{l}\text { culture in } \\
\text { nanofibrous } \\
\text { scaffolds }\end{array}$ & $\begin{array}{l}\text { human bone } \\
\text { marrow } \\
\text { derived MSCs }\end{array}$ & $\begin{array}{c}\text { multi-lineage } \\
\text { differentiation of MSCs }\end{array}$ & {$[74]$} \\
\hline & $\begin{array}{c}\text { immobilized } \\
\text { TGF- } \beta 3 \\
\text { lentivirus to } \\
\text { woven scaffolds } \\
\text { and cultured } \\
\text { cells }\end{array}$ & human MSCs & $\begin{array}{c}\text { formation of } \\
\text { cartilaginous } \\
\text { extracellular matrix; } \\
\text { induced chondrogenesis } \\
\text { as effectively as with } \\
\text { TGF- } \beta 3 \text { supplemented } \\
\text { medium }\end{array}$ & {$[85]$} \\
\hline \multirow[t]{2}{*}{$\begin{array}{l}\text { poly(ethylene } \\
\text { glycol) (PEG) }\end{array}$} & $\begin{array}{l}\text { incorporated } \\
\text { cleavable RGD } \\
\text { peptide into } \\
\text { hydrogels and } \\
\text { encapsulated } \\
\text { cells }\end{array}$ & human MSCs & $\begin{array}{c}\text { RGD promoted } \\
\text { chondrogenesis of } \\
\text { MSCs, MMP-13 } \\
\text { produced by cells led to } \\
\text { the release of RGD as } \\
\text { necessary for complete } \\
\text { differentiation of cells as } \\
\text { limited by the presence } \\
\text { of RGD }\end{array}$ & {$[75]$} \\
\hline & $\begin{array}{c}\text { cell } \\
\text { encapsulation in } \\
\text { photopolymerized } \\
\text { hydrogels }\end{array}$ & $\begin{array}{c}\text { bovine } \\
\text { condylar } \\
\text { chondrocytes }\end{array}$ & $\begin{array}{c}\text { cell viability was } \\
\text { maintained and PEG } \\
\text { hydrogels are suitable } \\
\text { for cell encapsulation }\end{array}$ & {$[76]$} \\
\hline
\end{tabular}




\begin{tabular}{|c|c|c|c|c|}
\hline Biomaterial & Methods & Cells Used & Significant Results & Ref. \\
\hline $\begin{array}{c}\text { composite } \\
\text { polyglycolic } \\
\text { acid/polyethylene }\end{array}$ & $\begin{array}{c}\text { polyethylene } \\
\text { cylindrical rods } \\
\text { were wrapped } \\
\text { with PGA fibres, } \\
\text { seeded with cells, } \\
\text { cultured with } \\
\text { TGF- } \beta 1 \text { and IGF-1 } \\
\text { and implanted } \\
\text { into mice } \\
\text { subcutaneously }\end{array}$ & $\begin{array}{l}\text { porcine bone } \\
\text { marrow } \\
\text { MSCs }\end{array}$ & $\begin{array}{c}\text { formation of mature } \\
\text { cartilage after } 8 \text { weeks }\end{array}$ & [77] \\
\hline $\begin{array}{c}\text { composite } \\
\text { polyglycolic } \\
\text { acid/ } \\
\text { hydroxyapatite }\end{array}$ & $\begin{array}{l}\text { seeding onto } \\
\text { scaffolds and } \\
\text { implantation into } \\
\text { full thickness } \\
\text { cartilage defects }\end{array}$ & rabbit MSCs & $\begin{array}{c}\text { formation of hyaline } \\
\text { cartilage and } \\
\text { subchondral bone }\end{array}$ & [78] \\
\hline
\end{tabular}

Polyglycolic and poly-L-lactic based scaffolds have been generally found to increase the presence of proteoglycans as well as the proliferation and differentiation of chondrocytes, as compared to collagen based scaffolds [68]. Baek et al. [69] seeded in vitro cultured chondrocytes onto PLGA scaffolds, and the tissue constructs were implanted in the subcutaneous pocket of nude mice. After 4 months of implantation, neocartilage was formed with the same dimensions of the scaffold. The explants showed chondrocytes within lacunae in a mature cartilaginous matrix that expressed collagen type II. Rabbit chondrocytes seeded on PLGA microspheres of 30-80 $\mu \mathrm{m}$ in diameter showed good adhesion to the microsphere surface [70]. In vivo, chondrocytes mixed with these PLGA microspheres were injected into subcutaneous sites in mice, and solid white cartilaginous tissues were formed in the implantation site after 4 and 9 weeks. The resulting tissues appeared histologically mature and expressed high levels of sulfated GAGs and collagen. As well, PLGA scaffolds allow the differentiation of progenitor cells and provide structural support for chondrogenesis and articular cartilage repair [71]. Uematsu et al. [71] seeded MSCs onto 3D PLGA scaffolds and transplanted them into defects in rabbit knees. At 12 weeks after transplantation, the defects were filled with smooth white tissues that were hyaline-like. Zwingmann et al. [72] seeded human chondrocytes onto PGA and PLGA scaffolds. The synthesis of aggrecan and the mRNA gene expression for collagen II were higher in PGA groups.

Porous PCL scaffolds with pore size of 100-150 $\mu \mathrm{m}$ were used to culture MSCs for 3 weeks in vitro [73]. These cell-scaffold complexes became harder and easily manipulated after 3 weeks. When the PCL scaffolds were treated with 
Pluronic F127 and / or collagen, the resulting tissues had higher DNA and GAG contents and showed more chondrogenic differentiation. PCL was also used to fabricate 3D nanofibrous scaffolds for the culture and multi-lineage differentiation of human bone marrow derived MSCs [74].

PEG hydrogels are commonly used for cell encapsulation because their hydrolytic degradation can be tunable. Salinas et al. [75] incorporated cleavable arginylglycylaspartic acid (RGD) peptide sequence into PEG hydrogels by using a thiol-acrylate photo-polymerization. RGD has been shown to promote the survival and induce chondrogenesis of human MSCs in PEG hydrogels, but it limits complete differentiation of cells with its sustained presence. By including an MMP-13 specific cleavable linker to the peptide sequence, RGD could be released from the hydrogels with the production of MMP-13 by encapsulated cells. After 21 days, MSCs in RGD-releasing hydrogels produced more GAG and collagen II as compared with hydrogels with uncleavable RGD. In a separate study, Nicodemus et al. [76] encapsulated condylar chondrocytes in photopolymerized PEG hydrogels. PEG hydrogels were found suitable for cell encapsulation as the cell viability was maintained over the culture period.

Composite scaffolds can be fabricated using multiple biomaterials. Zhu et al. [77] created a PGA/polyethylene composite scaffold, with high density polyethylene carved into cylindrical rods and wrapped with PGA fibres. Porcine bone marrow MSCs were seeded into the scaffolds and cultured for 3 weeks in chondrogenic medium containing TGF- $\beta 1$ and insulin-like growth factor (IGF-1). The resulting tissue constructs were implanted subcutaneously into mice. At 8 weeks post-implantation, mature cartilage was formed around the polyethylene as well as inside the pores of the polyethylene scaffold. Zhou etal. [78] evaluated a composite scaffold made of PGA and hydroxyapatite. Rabbit MSCs were seeded onto PGA and hydroxyapatite scaffolds, and the cell-seeded PGA and hydroxyapatite constructs joined together after $72 \mathrm{~h}$. The cell-PGA-hydroxyapatite composite constructs were implanted into full thickness cartilage defects in the intercondylar fossa of the femur, resulting in the formation of hyaline cartilage and a complete subchondral bone formation.

A combination of natural and synthetic biomaterials can also be used for cartilage tissue engineering to synergize the biomimetic properties of natural materials and the tunable mechanical properties of synthetic materials. Sha'ban et al. [79] seeded rabbit articular chondrocytes in fibrin onto PLGA scaffolds to minimize cell loss during seeding and to achieve homogeneous cell distribution. This hybrid scaffold was capable of promoting in vitro chondrogenesis and led to greater sulphated GAG production as compared with PLGA control. Yoo et al. [80] immobilized hyaluronic acid onto macroporous PLGA scaffolds to enhance the attachment of chondrocytes as well as the synthesis of GAG and collagen compared to unmodified PLGA scaffolds. Human adipose derived stem cells cultured on hyaluronic 
acid-modified PLGA scaffolds expressed higher levels of chondrogenic marker genes and increased in the production of sulphated GAG and collagen II, as compared to those cultured in unmodified PLGA scaffolds at 4 weeks [81].

Bioactive molecules such as peptides and growth factors can be incorporated and delivered in biomaterials for cartilage tissue engineering. Growth factors such as FGF, TGF- $\beta 1$ and IGF-1 have been shown to enhance chondrogenesis $[63,82,83]$. Cai et al. [61] loaded chitosan microspheres with TGF- $\beta 1$, and rabbit chondrocytes were cultured on chitosan scaffolds with the TGF- $\beta 1$ microspheres for 3 weeks. TGF- $\beta 1$ could be released from the microspheres in a controlled multiphasic manner and stimulated cell proliferation and the synthesis of collagen type II. Another chondrogenic differentiation factor, bone morphogenetic protein-6 (BMP-6), was loaded onto chitosan scaffolds and increased the contents of GAG, collagen II and DNA in cultured cell-scaffold constructs [84].

Brunger etal. [85] created lentivirus-based cell-instructive scaffolds to mediate the differentiation of human mesenchymal stem cells and increase the formation of cartilaginous extracellular matrix. This was done by using poly-L-lysine to immobilize transforming growth factor $\beta 3$ (TGF- $\beta 3$ ) lentivirus to $3 \mathrm{D}$ woven PCL scaffolds. The gene delivery of TGF- $\beta 3$ using the scaffolds induced chondrogenesis as effectively as the conventional differentiation method with TGF- $\beta 3$ supplemented medium. Immobilization of the lentiviral vector to a biomechanically functional scaffold enabled sustained transgene expression and extracellular matrix formation.

There is increasing evidence that cell behavior can be influenced by changes in nanoscale topographical surfaces. Various studies have been performed to create and evaluate new biomaterials with such features. Nanomaterials used in cartilage tissue engineering will be further discussed in Section 16.4.

The use of scaffolds in conventional cartilage tissue engineering provides a structural support for the growth of cells and eases the shaping of the constructs, but can elicit immunological responses once implanted into the body. Whitney et al. [86] explored the scaffold-free method of cartilage tissue engineering, seeding high densities of cells (1-3 million cells $\left.\mathrm{cm}^{-2}\right)$ in a custom biochamber with two compartments separated by a porous polyester membrane. This method produces cartilage sheets of approximately $4 \mathrm{~cm}$ by $4 \mathrm{~cm}$. The Waldman group developed a method to grow large articular and auricular cartilage constructs from a small cell population (700013000 cells $\mathrm{cm}^{-2}$ ) without the use of scaffolds [53,87]. In this method, cells are seeded directly into the wells of a chamber, which is connected to a pump that provides a continuous flow of culture medium. After 4 weeks, 3D tissues that take the shape of the well $\left(3 \mathrm{~cm}^{2}\right)$ and have a thickness of approximately $500 \mu \mathrm{m}$ are formed. This continuous flow bioreactor setup improves the transport of nutrients and metabolic waste to promote tissue growth. 


\subsubsection{Bioreactors}

Cartilage tissue constructs can be grown in bioreactors that control the environmental conditions and provide specific factors for desired tissue growth. Bioreactors can maintain physiological conditions, improve transport of nutrients and wastes, and provide biomimetic stimulation.

The simplest form of the bioreactor is the cultivation of tissue constructs in a Petri dish or culture plate with or without placing it on a shaker $[88,89]$. Other bioreactors include spinner flasks, flasks with stirrers and rotating vessels [90-93]. These bioreactors provide shear stress to the tissue constructs to enhance nutrition by convection as opposed to diffusion alone. Rotating vessels are more advanced bioreactors that allow tissue constructs to float freely in the culture medium while the vessel rotates around an axis at a constant speed. It was previously shown that chondrocyte-seeded scaffolds cultured in rotating vessels for 8 weeks resulted in larger constructs than those cultured in static and stirred bioreactors [93]. Constructs grown in rotating bioreactors also had the highest concentrations of glycosaminoglycan and collagen and the best mechanical properties.

\subsection{Control of oxygen tension}

Cultured cells require nutrients and oxygen to proliferate. In static culture, oxygen and carbon dioxide diffuse into and out of the cells. As a result, the medium close to the cells has a decreasing oxygen tension and increasing carbon dioxide tension. If the medium is not circulated, the rate of diffusion into the cells decreases and eventually ceases due to the lack of concentration gradient of oxygen across the cell surface. This leads to cell death. Stirred flask bioreactors can provide shear stresses and enable the mixing of oxygen and nutrients throughout the culture medium during the cultivation of cells for cartilage tissue engineering. As chondrocytes are primarily anaerobic cells, several studies have investigated the effects of oxygen tension on tissue formation. The effects of hypoxia are variable, with some studies indicating that hypoxia leads to improvements in tissue formation [94], whereas others have shown no effects [95].

\subsection{Transport of nutrients and metabolic waste}

Continuous flow bioreactors can be used for the engineering of various cartilaginous tissues so as to eliminate the need for large numbers of cells as with other approaches and to accelerate the formation of engineered tissues. Previous approaches of cartilage tissue engineering required a large number of cells to generate tissues of physiologically relevant size and mechanical properties. For example, cell density of $10^{6}$ cells cm$^{-2}$ is necessary to engineer nasal cartilage tissues that can withstand surgical manipulations and support the structure of the nose [96]. A separate cell expansion stage is usually used to obtain a large number of cells for cartilage tissue engineering. This expansion 
stage tends to lead to de-differentiation of cartilage cells. Brenner et al. [87] developed a novel strategy to engineer cartilage tissues of $3 \mathrm{~cm}^{2}$ from a small population of cells (only $10^{4}$ cells $\mathrm{cm}^{-2}$ ) without the cell expansion step, by growing tissues in a continuous flow bioreactor. Also, the continuous flow bioreactor can accelerate matrix production compared to static growth such that no scaffold will be necessary. Using a bioreactor with media flow likely improves tissue growth due to better transport of nutrients and metabolic waste.

\subsection{Growth factors}

Bioreactors can provide more suitable culture conditions to tissue constructs by adding growth factors that support chondrogenesis. The application of growth factors such as bone morphogenetic protein-2 (BMP-2), IGF-1, and TGF- $\beta$ ( 1 or 3 ) in the bioreactor increased the compressive and tensile properties of engineered cartilage tissues [97]. The proliferation of chondrocytes, when seeded at low densities, was increased by adding combinations of growth factors such as TGF- $\beta 1$, fibroblast growth factor 2 (FGF-2) and platelet-derived growth factor BB (PDGF-BB) into the bioreactor [98]. In a separate study, elastic cartilage constructs grown by culturing rabbit auricular chondrocytes in the continuous flow bioreactor showed increased deposition of cartilaginous extracellular matrix, improved expression and localization of elastin, improved mechanical properties and greater thickness when insulin or IGF-1 was added [99]. These constructs had properties comparable to the native auricular cartilage after a 4 week cultivation period. On the other hand, the inhibition of interleukin- 6 may improve the growth of cartilage constructs in bioreactors [100].

\subsection{Application of mechanical forces}

The function of chondrocytes can also be influenced by mechanical signals. The application of mechanical forces can be transduced into biochemical signals leading to the stimulation of cartilaginous extracellular matrix synthesis (process of mechanotransduction). In addition, mechanical stimulation of tissue engineered cartilage can also result in the improvement of mechanical properties of the developed tissue constructs. These applied forces simulate loading that would be normally exerted during activities of daily movement. Specifically, cyclical loading of articular chondrocytes has been shown to increase extracellular matrix production and cell viability within engineered cartilage constructs $[101,102]$. Other bioreactors have been developed to provide dynamic changes in hydrostatic pressure, tension, shear, vibrations, etc. to articular cartilage in vitro, which are reviewed in [103]. For example, shear stresses can also be applied to cartilage tissue constructs using rotating vessels as described previously (Section 16.3.2.3.). 


\subsection{NANOMATERIALS FOR CARTILAGE TISSUE ENGINEERING}

New methods in nanomaterial science, such as electrospinning and 3D fibre deposition, have been developed to improve the quality of the scaffolds on the nanoscale. Similarly, nanoparticles can also be incorporated into biomaterials. The addition of these nanoscale features can produce scaffolds that better mimic the extracellular matrix environment found in the native cartilage, which is believed to increase the interaction of the cells with the scaffold to improve the functionality of the resultant engineered tissue construct. It is believed that cell behavior is largely affected by nanoscale features, leading to changes in the cytoskeleton, cell morphology, focal adhesions, motility as well as gene expression. Studies have suggested that there may be a topography-dependent cell transduction that is independent of biochemical signals, and this is related to the pattern and spacing of adhesive ligands [104,105]. This type of cell transduction has been found to be similar to mechanotransduction $[105,106]$.

\subsubsection{Nanosurfaces}

Both physical (i.e. lithography) and chemical (i.e. treatment with acids and bases) methods have been used to create geometrically defined nanopatterns on tissue engineering scaffolds (Figure 4). Balasundaram et al. [107] created highly porous surfaces with nanoscale roughness by nanoembossing polyurethane (PU) and PCL. The two polymers were casted over a crystalline titanium surface with plasma-deposited spiky nanofeatures, which can be modified using different parameters for the fabrication process. The resulting polyurethane and PCL surfaces have nanoscale surface roughness and high surface energy compared to surfaces casted over titanium without spikes. These surfaces increased chondrocyte numbers, intracellular protein production and collagen secretion by chondrocytes compared with smooth surfaces. Park et al. [108] modified PLGA scaffolds using a chemical etching technique with $1 \mathrm{~N}$ sodium hydroxide for $10 \mathrm{~min}$. The treated PLGA scaffolds enhanced chondrocyte numbers as well as intracellular and extracellular protein content compared to untreated PLGA scaffolds. This may be due to increased hydrophilicity, porosity, surface area and degree of nanometer roughness. The authors suggest chemically treated PLGA may be suitable for articular cartilage repair. 


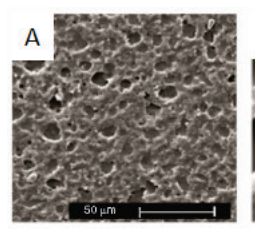

D

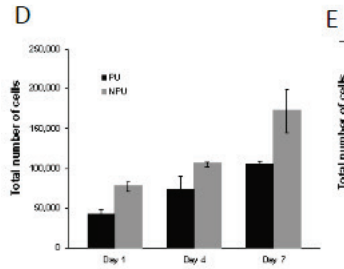

E

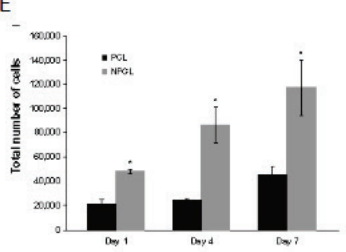

F

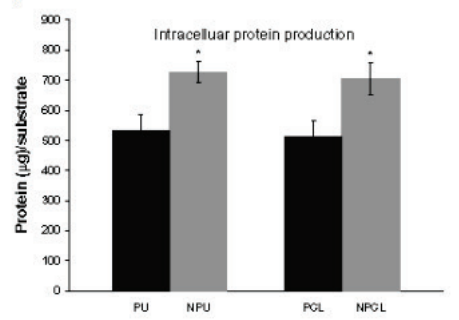

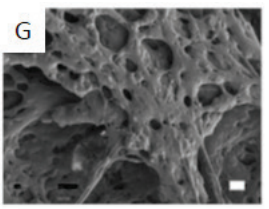
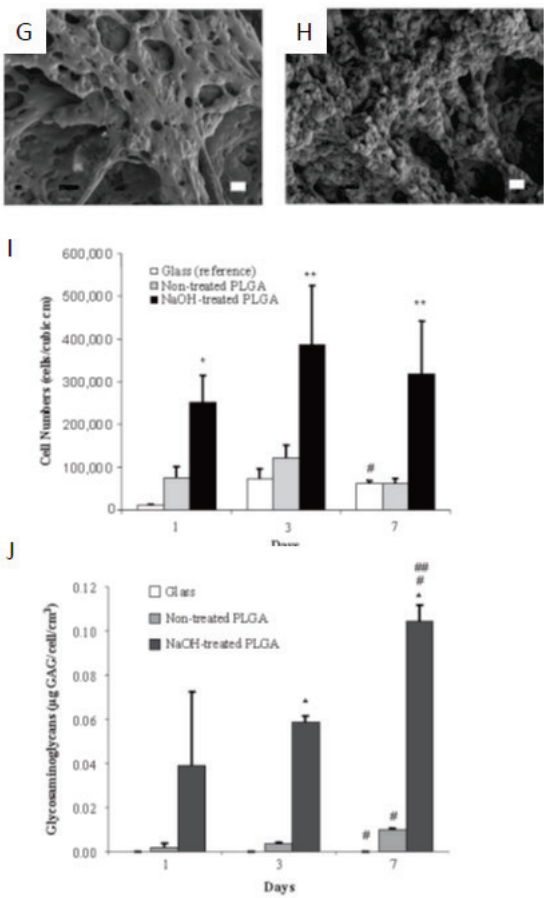

Figure 4. Nanosurfaces created with physical and chemical methods for cartilage tissue engineering. (A-F) Nanoembossed polyurethane (NPU) and nanoembossed polycaprolactone (NPCL) [107]. (A-B) Scanning electron microscopy images of NPU at low (A) and high (B) magnifications. (C) Scanning electron microscopy image of NPCL.

(D-E) Chondrocyte density was increased on NPU (D) and NPCL (E) compared to unmodified substrates (PU, PCL). (F) Intracellular protein production was increased on NPU and NPCL compared to unmodified substrates. (G-J) NaOH-treated PLGA scaffold

[108]. (G-H) Scanning electron microscopy images of unmodified (G) and $\mathrm{NaOH}$-treated (H) PLGA scaffolds. (I) Cell density was increased on $\mathrm{NaOH}$-treated scaffolds compared to unmodified scaffolds. (J) GAG synthesis was increased on $\mathrm{NaOH}$-treated scaffolds compared to unmodified scaffolds.

\subsubsection{Nanofibres}

Nanofibrous scaffolds are commonly prepared using electrospinning (Figure 5). Li etal. [44,74] fabricated electrospun, three-dimensional nanofibrous scaffolds from a synthetic biodegradable polymer, PCL. The resulting scaffolds had uniform, randomly oriented nanofibres of $700 \mathrm{~nm}$ in diameter. These scaffolds resemble collagen fibrils and supported the multi-lineage differentiation of bone marrow-derived human mesenchymal stem cells when cultured in specific differentiation media in vitro. Specifically the cartilage specific gene profile, including aggrecan, collagen II and collagen $\mathrm{X}$, was expressed when cells were grown in chondrogenic medium with TGF- $\beta 1$. 

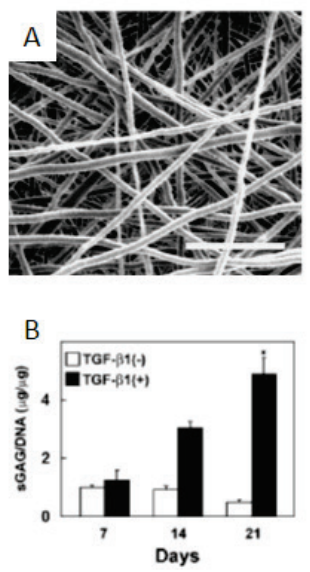
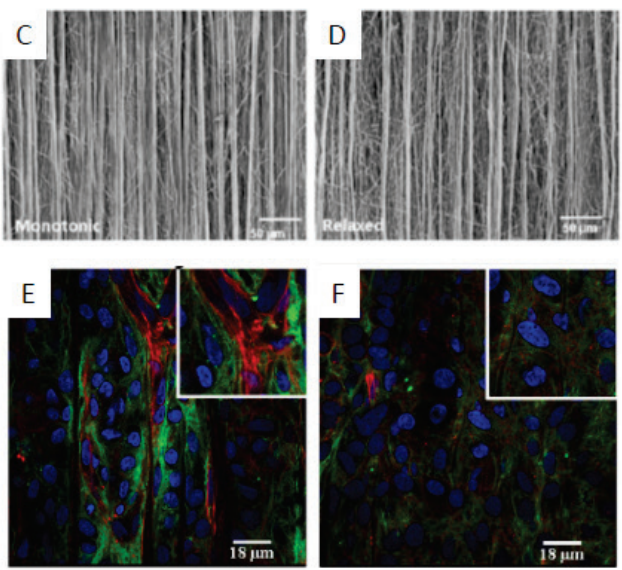
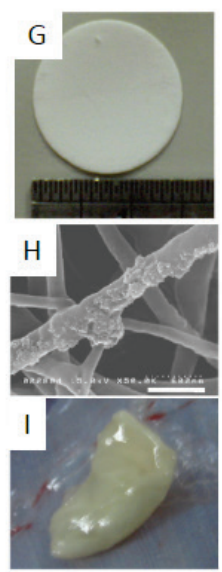

Figure 5. Nanofibrous scaffolds used in cartilage tissue engineering. (A-B) Electrospun nanofibrous polycaprolactone scaffold [44]. (A) Scanning electron microscopy image of polycaprolactone scaffold with fibres of 500-900 nm in diameter. (B) GAG synthesis was increased when MSC cultures on the nanofibrous scaffolds were treated with TGF- $\beta 1$. (C-F) Aligned electrospun nanofibrous polycarbonate urethane scaffolds modified with an anionic dihydroxyl oligomer [110]. (C-D) Scanning electron microscopy images of scaffolds under continuous tension (monotonic) (C) or with tension only for $24 \mathrm{~h}$ (relaxed) (D). (E-F) Type I collagen (green) appeared more organized parallel to the cells (red, actin cytoskeleton; blue, cell nuclei) in monotonic scaffolds (E) than in relaxed scaffolds (F). (G-I) Electrospun nanofibrous poly(lactic acid) membranes modified by treatment with oxygen plasma and subsequent covalent grafting of cationized gelatin molecules [112]. (G) Bulk appearance of nanofibrous membrane before implantation into rabbits subcutaneously. (H) Scanning electron microscopy image of nanofibrous membrane. (I) Bulk appearance of tissue constructs 4 weeks after implantation into rabbits subcutaneously.

In vivo, electrospun PCL scaffolds with fibres of $400 \mathrm{~nm}$ in diameter, coated with chitosan or uncoated, were implanted under periosteum in rabbits and TGF- $\beta 1$ or vehicle was injected into the implant site [109]. The scaffolds were removed after 1, 3, 5 or 7 days and the scaffolds and periosteum were cultured separately for 6 weeks. The longer duration of implantation led to increased cartilage formation in the uncoated scaffolds. Cells in the uncoated scaffolds produced more GAG and cartilage compared to those in chitosan-coated scaffolds. Overall, these nanofibre scaffolds allowed infiltration of periosteal cells in vivo, which in turn produced engineered cartilage in vitro.

Turner et al. [110] cultured bovine annulus fibrosus cells on electrospun-aligned nanofibrous polycarbonate urethane scaffolds, and the constructs were strained under tension either throughout the entire culture duration (monotonic condition) or only for the first $24 \mathrm{~h}$ (relaxed condition). Cells on the relaxed scaffolds showed increased proliferation and collagen synthesis. On the other hand, the cells and matrix on the monotonic strained scaffolds 
were more aligned, which in turn led to higher elastic modulus. Determining the optimal applied tensile forces and elastic modulus for the tissue engineering of the annulus fibrosus, a fibrocartilage within the intervertebral disc, may be necessary to better mimic the native tissue.

Besides electrospinning, thermally induced phase separation can also be used to fabricate nanofibrous scaffolds [111]. A poly $(\beta$-caprolactone)-block-poly(L-lactide) (PCL-b-PLLA) copolymer was used to fabricate nanofibrous scaffolds using this method. PCL-b-PLLA / tetrahydrofuran solution, with the addition of particles of $125-200 \mu \mathrm{m}$, was quenched to $-20^{\circ} \mathrm{C}$ or below and then gelled for $2 \mathrm{~h}$ due to the PCL and PLLA microcrystals. The gel was immersed in water for 2 days to leach out the particles and then lyophilized to obtain nanofibrous scaffolds. The nanofibrous scaffold had higher specific surface area and protein adsorption compared to a solid-walled scaffold. Chondrocytes cultured on the nanofibrous scaffold showed spherical chondrocyte-like phenotype, produced greater amounts of proteins and DNA, and expressed higher levels of collagen II and aggrecan mRNA.

Electrospun PLLA nanofibrous membranes were modified by treatment with oxygen plasma to introduce carboxylate groups on the surface, onto which cationized gelatin molecules were covalently grafted [112]. In vitro, the modified membranes enhanced the viability, proliferation and differentiation of rabbit articular chondrocytes compared to unmodified membranes. Cells had proper morphology and grew into the interior of the membranes, as shown by scanning electron microscopy. Cell differentiation was evident by the increased secretion of glycosaminoglycan and collagen and expression of characteristic markers of chondrocytes, such as collagen II, aggrecan and Sox9. In vivo, the subcutaneous implantation of cell-seeded membranes led to the formation of cartilage tissues after 28 days.

\subsubsection{Nanocomposites}

While polymer-hydroxyapatite nanoparticle composites are extensively explored for bone repair, they may also be used for cartilage regeneration (Figure 6). Spadaccio et al. [113] investigated the use of electrospun fibres of PLLA loaded with hydroxyapatite nanoparticles for the chondrogenic differentiation of human MSCs. These composite scaffolds induced the chondrogenic differentiation of MSCs, as evident in Sox9 expression and the presence of cartilage specific proteoglycans, compared to a PLLA control. Sox 9 is a chondrogenic transcription factor that activates the production of collagen type II and aggrecan. Pan et al. [114] prepared nanohydroxyapatite reinforced poly(vinyl alcohol) (PVA)composite gels by an in situ synthesis of nanohydroxyapatite particles in PVA solution combined with a freeze / thaw technique. The mechanical properties of the hydrogel could be modified to mimic those of the articular cartilage by changing the nanohydroxyapatite content, PVA concentration and freeze / thaw cycle times. 

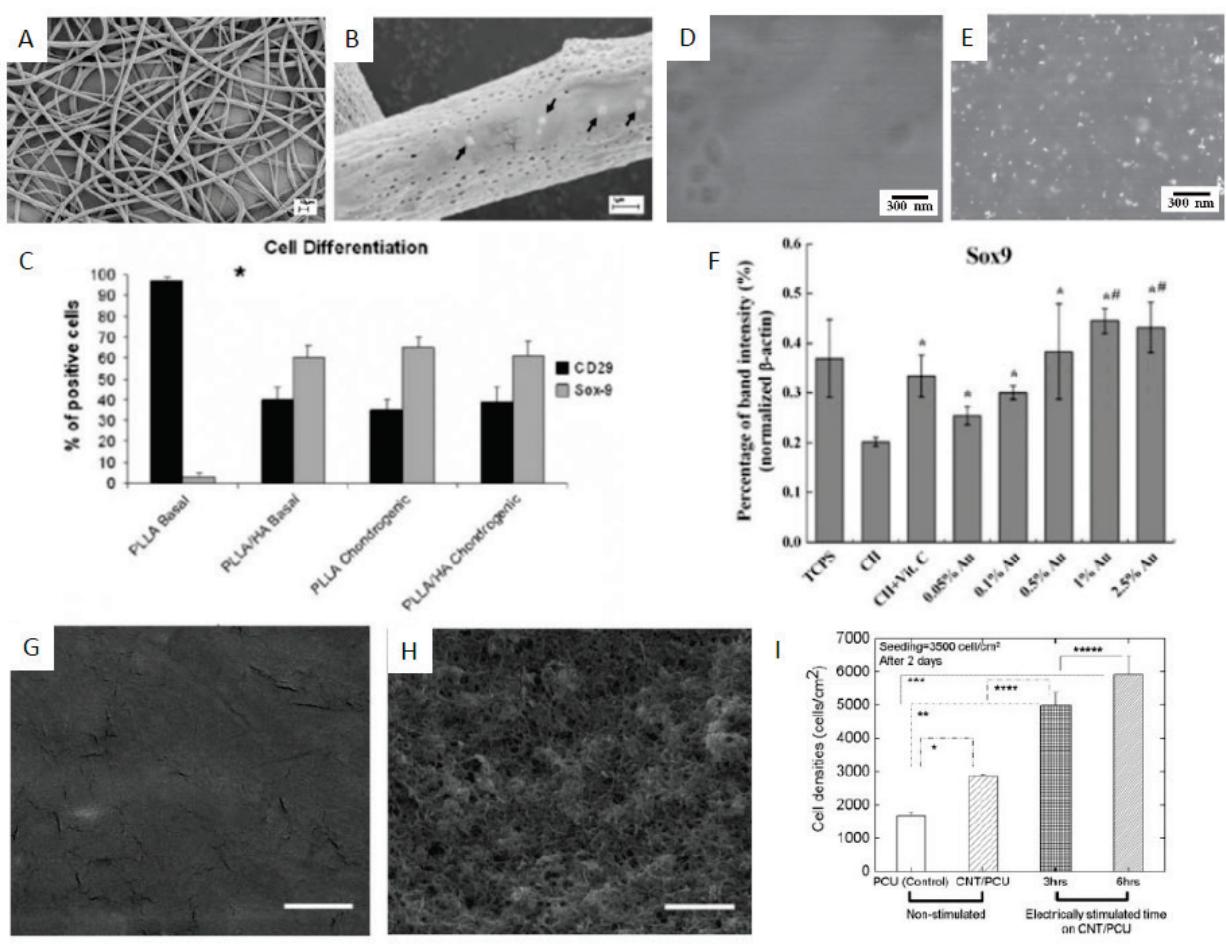

Figure 6. The incorporation of nanoparticles and nanotubes into scaffolds for cartilage tissue engineering. (A-C) The incorporation of hydroxyapatite nanoparticles into poly(lactic acid) scaffolds [113]. (A-B) Scanning electron microscopy images of poly(lactic acid) membranes with hydroxyapatite nanoparticles at low (A) and high (B) magnifications (nanoparticles indicated with arrows). (C) The expression of chondrogenic specific marker Sox-9 in human MSCs was increased when cultured in basal medium on poly(lactic acid) scaffold with hydroxyapatite nanoparticles (PLLA-HA Basal) compared to poly(lactic acid) only control (PLLA Basal). (D-F) The incorporation of gold nanoparticles into type II collagen [115]. (D-E) Scanning electron microscopy images of surfaces of type II collagen only (D) and type II collagen with $2.5 \%$ gold nanoparticles (E). (F) Expression of Sox-9 was increased with the addition of gold nanoparticles compared to type II collagen only (CII). (G-I) The incorporation of carbon nanotubes into polycarbonate urethane [119]. (G-H) Scanning electron microscopy images of bare polycarbonate urethane surface (PCU) (G) and PCU with carbon nanotubes (H). (I) Chondrocyte density was increased on electrically stimulated PCU with carbon nanotubes (CNT/PCU) compared to bare PCU.

Metallic nanoparticles, such as gold, have certain optical, electronic and biological properties beneficial for cartilage repair. Researchers have incorporated these nanoparticles into polymers to fabricate polymer-metal nanoparticle composites for cartilage tissue engineering. Hsu et al. [115] incorporated gold nanoparticles into hydrogels made of porcine collagen II. These nanoparticles increased mechanical properties. At $0.1 \%$ gold 
nanoparticles, the composite hydrogels promoted chondrocyte proliferation. An increased gold nanoparticle content led to increased expression of collagen I, aggrecan and Sox 9 , up to $2.5 \%$ gold content.

The type and amount of nanoparticles incorporated in the nanocomposite scaffolds can be changed to modify surface properties such as surface area, roughness and charge, which may affect the adhesion and proliferation of chondrocytes. Compared with surfaces with conventional or microscale surface roughness, the adhesion of chondrocytes increased on PLGA / titanium dioxide (titania) composite scaffolds with a nanosurface [116]. The scaffolds were created by adding nanometer grain size titania to PLGA solution to create PLGA / titania composites and then chemically treating the composites with different concentrations of sodium hydroxide for different time periods to obtain surface features. Moreover, it was found that these PLGA/titania composites increased the intracellular synthesis of alkaline phosphatase and chondrocyte-expressed growth factors, compared to unmodified surfaces.

Carbon nanotubes have desirable mechanical and electrical properties for tissue engineering. The native extracellular matrix has a natural nanotopography that supports cell attachment and interactions, in turn affecting cell morphology and arrangement. This nanotopography could be mimicked using the structural arrangements of carbon nanotubes. In addition, it was previously shown that electric fields affect the growth and remodeling of cartilage [117,118]. Khang et al. [119] investigated the effect of surface roughness and electrical stimulation on the functions of chondrocytes using composite film made of carbon nanotubes and polycarbonate urethane. The composite film had higher nanometer surface roughness and is more hydrophilic compared to plain polymer, which enhanced chondrocyte adhesion and cell density. A lateral electrical stimulation of low voltage was applied across the composite films and this was shown to further enhance cell density. Carbon nanotubes can also be physically entrapped into collagen matrix to better mimic the natural extracellular matrix [120].

A nanoparticle/hydrogel system was developed for delivering two growth factors, BMP-7 and TGF- $\beta 2$, to promote the chondrogenesis of MSCs [121]. The alginate hydrogel contains BMP-7 and polyion complex nanoparticles with TGF- $\beta 2$, such that a fast release of BMP-7 and a slow release of TGF- $\beta 2$ occur. 


\subsection{CONCLUSIONS}

Despite advancements in scaffold design and bioreactor conditions, engineered cartilage constructs remain mechanically inferior to native cartilage tissues. In addition, engineered tissues thus far showed poor integration as well as deterioration in its quality over time when evaluated in vivo. The development of new nanomaterials with desired properties may improve chondrogenesis, resulting in more suitable tissue grafts for cartilage repair and regeneration. Here, the recent progress in the development of these materials has been discussed. Some of the recent studies in cartilage tissue engineering involve nanosurfaces fabricated using lithography or acid/base treatments, nanofibrous scaffolds fabricated by electrospinning or thermally induced phase separation, and nanocomposites fabricated by adding nanoparticles or carbon nanotubes to scaffolds. The introduction of nanoscale features creates scaffolds that more closely resemble the native cartilage in its extracellular matrix structure. This improves the interaction of cells with the scaffold and in turn tissue growth. Nanomaterials have shown success in enhancing cell adhesion, morphology, growth, differentiation and synthesis of cartilaginous extracellular matrix. Future work in this field should continue to develop nanocomposites with both mechanical and biochemical properties that adequately mimic the human cartilage tissue such that the morphological and functional properties of the resultant engineered cartilage tissue can be suitable for eventual clinical translation. 


\section{REFERENCES}

1. J. Raghunath, J. Rollo, K.M. Sales, P.E. Butler, A.M. Seifalian. Biotechnol. Appl. Biochem. 46 (2007) 73-84.

2. A.M. Bhosale, J.B. Richardson. Br. Med. Bull. 87 (2008) 77-95.

3. L. Nayyer, K.H. Patel, A. Esmaeili, R.A. Rippel, M. Birchall, G.O'Toole, P.E. Butler, A.M. Seifalian. Plast. Reconstr. Surg. 129 (2012) 1123-1137.

4. D.V. Luquetti, E. Leoncini, P. Mastroiacovo. Birth Defects Res. A. Clin. Mol. Teratol. 91 (2011) 813-822.

5. D. Erdmann, K.E. Follmar, M. Debruijn, A.D. Bruno, S.H. Jung, D. Edelman, S. Mukundan, J.R. Marcus. Ann. Plast. Surg. 60 (2008) 398-403.

6. P.D. Phelps, D. Poswillo, G.A. Lloyd. Clin. Otolaryngol. Allied Sci. 6 (1981) 15-28.

7. Y. Wang, R. Xiao, F. Yang, B.O. Karim, A.J. Iacovelli, J. Cai, C.P. Lerner, J.T. Richtsmeier, J.M. Leszl, C.A. Hill, K. Yu, D.M. Ornitz, J. Elisseeff, D.L. Huso, E.W. Jabs. Development 132 (2005) 3537-3548.

8. K. Kojima, L.J. Bonassar, A.K. Roy, H. Mizuno, J. Cortiella, C.A. Vacanti. FASEB J. 17 (2003) 823-828.

9. S.C. Elkerbout, R.A. van Lingen, J. Gerritsen, R.J. Roorda. Arch. Dis. Child. 68 (1993) 37-40.

10. J.A. Buckwalter, H.J. Mankin. Instr. Course Lect. 47 (1998) 477-486.

11. P.J. Roughley. Eur. Cell Mater. 12 (2006) 92-101.

12. M. Benjamin, E.J. Evans. J. Anat. 171 (1990) 1-15.

13. R.M. Aspden, Y.E. Yarker, D.W. Hukins. J. Anat. 140 (Pt 3) (1985) 371-380.

14. S.N. Redman, S.F. Oldfield, C.W. Archer. Eur. Cell Mater. 9 (2005) 23-32.

15. Y. Matsusue, T. Yamamuro, H. Hama. Arthroscopy 9 (1993) 318-321.

16. L. Hangody, G. Kish, Z. Karpati, I. Udvarhelyi, I. Szigeti, M. Bely. Orthopedics 21 (1998) 751-756.

17. L. Hangody, P. Fules. J. Bone Joint Surg. Am. 85A (Suppl 2) (2003) 25-32.

18. R. Gudas. Medicina (Kaunas) 38 (2002) 52-57.

19. G.N. Homminga, S.K. Bulstra, P.S. Bouwmeester, A.J. van der Linden. J. Bone Joint Surg. Br. 72 (1990) 1003-1007.

20. V.A. Ritsila, S. Santavirta, S. Alhopuro, M. Poussa, H. Jaroma, J.M. Rubak, A. Eskola, V. Hoikka, O. Snellman, K. Osterman. Clin. Orthop. Relat. Res. 302 (1994) 259-265.

21. T.E. Orr, A.M. Patel, B. Wong, G.P. Hatzigiannis, T. Minas, M. Spector. J. Biomed. Mater. Res. 44 (1999) 308-313.

22. H. Alfredson, R. Lorentzon. Ortop. Traumatol. Rehabil. 3 (2001) 216-223.

23. A.O. Oseni, P.E. Butler, A.M. Seifalian. Ann. Plast. Surg. 71 (2013) 238-244.

24. E. Letang, J. Sanchez-Lloret, J.M. Gimferrer, J. Ramirez, A. Vicens. Ann. Thorac. Surg. 49 (1990) 955-958.

25. P.C. Cavadas. Plast. Reconstr. Surg. 101 (1998) 937-942.

26. A. Messineo, R.M. Filler, T. Joseph, A. Bahoric, C.R. Smith. J. Pediatr. Surg. 29 (1994) 697-700.

27. K. Kushibe, T. Tojo, H. Sakaguchi, M. Takahama, K. Nishizaki, K. Nezu, S. Taniguchi. Ann. Thorac. Surg. 70 (2000) 1876-1879.

28. J.L. Graziano, A. Spinazzola, W.E. Neville. Ann. Thorac. Surg. 4 (1967) 1-11.

29. N. Okumura, T. Nakamura, Y. Shimizu, T. Natsume, Y. Ikada. ASAIO Trans. 37 (1991) M317-319. 
30. J.C. Banis Jr., K. Churukian, M. Kim, J.M. Gu, G.L. Anderson, S. Kaneko, T. Keelen, J.H. Barker. Plast. Reconstr. Surg. 98 (1996) 1046-1051.

31. J.R. Steadman, W.G. Rodkey, K.K. Briggs. J. Knee Surg. 15 (2002) 170-176.

32. R.P. Ficat, C. Ficat, P. Gedeon, J.B. Toussaint. Clin. Orthop. Relat. Res. 144 (1979) 74-83.

33. G. Bachmann, E. Basad, D. Lommel, J. Steinmeyer. Radiologe 44 (2004) 773-782.

34. M. Ronga, F.A. Grassi, P. Bulgheroni. Arthroscopy 20 (2004) 79-84.

35. M. Brittberg, A. Lindahl, A. Nilsson, C. Ohlsson, O. Isaksson, L. Peterson. N. Engl. J. Med. 331 (1994) 889-895.

36. M. Brittberg, L. Peterson, E. Sjogren-Jansson, T. Tallheden, A. Lindahl. J. Bone Joint Surg. Am. 85A (Suppl 3) (2003) 109-115.

37. G. Knutsen, J.O. Drogset, L. Engebretsen, T. Grontvedt, V. Isaksen, T.C. Ludvigsen, S. Roberts, E. Solheim, T. Strand, O. Johansen. J. Bone Joint Surg. Am. 89 (2007) 2105-2112.

38. D.B. Saris, J. Vanlauwe, J. Victor, M. Haspl, M. Bohnsack, Y. Fortems, B. Vandekerckhove, K.F. Almqvist, T. Claes, F. Handelberg, K. Lagae, J. van der Bauwhede, H. Vandenneucker, K.G. Yang, M. Jelic, R. Verdonk, N. Veulemans, J. Bellemans, F.P. Luyten. Am. J. Sports Med. 36 (2008) 235-246.

39. S. Wakitani, T. Goto, S.J. Pineda, R.G. Young, J.M. Mansour, A.I. Caplan, V.M. Goldberg. J. Bone Joint Surg. Am. 76 (1994) 579-592.

40. J.P. Caffrey, A.M. Kushnaryov, M.S. Reuther, V.W. Wong, K.K. Briggs, K. Masuda, R.L. Sah, D. Watson. Otolaryngol. Head Neck Surg. 148 (2013) 576-581.

41. L.M. Ott, R.A. Weatherly, M.S. Detamore. Ann. Biomed. Eng. 39 (2011) 2091-2113.

42. S.D. Waldman, M.D. Grynpas, R.M. Pilliar, R.A. Kandel. J. Orthop. Res. 21 (2003) 132-138.

43. G.P. Dowthwaite, J.C. Bishop, S.N. Redman, I.M. Khan, P. Rooney, D.J. Evans, L. Haughton, Z. Bayram, S. Boyer, B. Thomson, M.S. Wolfe, C.W. Archer. J. Cell Sci. 117 (2004) 889-897.

44. W.J. Li, R. Tuli, C. Okafor, A. Derfoul, K.G. Danielson, D.J. Hall, R.S. Tuan. Biomaterials 26 (2005) 599-609.

45. B. Johnstone, T.M. Hering, A.I. Caplan, V.M. Goldberg, J.U. Yoo. Exp. Cell Res. 238 (1998) 265-272.

46. M.F. Pittenger, A.M. Mackay, S.C. Beck, R.K. Jaiswal, R. Douglas, J.D. Mosca, M.A. Moorman, D.W. Simonetti, S. Craig, D.R. Marshak. Science 284 (1999) 143-147.

47. J.U. Yoo, T.S. Barthel, K. Nishimura, L. Solchaga, A.I. Caplan, V.M. Goldberg, B. Johnstone. J. Bone Joint Surg. Am. 80 (1998) 1745-1757.

48. D.E. Ashhurst, B.A. Ashton, M.E. Owen. J. Orthop. Res. 8 (1990) 741-749.

49. J. Goshima, V.M. Goldberg, A.I. Caplan. Biomaterials 12 (1991) 253-258.

50. C. De Bari, F. Dell'Accio, P. Tylzanowski, F.P. Luyten. Arthritis Rheum. 44 (2001) 1928-1942.

51. T. Tallheden, J.E. Dennis, D.P. Lennon, E. Sjogren-Jansson, A.I. Caplan, A. Lindahl. J. Bone Joint Surg. Am. 85A (Suppl 2) (2003) 93-100.

52. S. Alsalameh, R. Amin, T. Gemba, M. Lotz. Arthritis Rheum. 50 (2004) 1522-1532.

53. R. Giardini-Rosa, P.P. Joazeiro, K. Thomas, K. Collavino, J. Weber, S.D. Waldman. Tissue Eng. Part A 20 (2014) 1012-1026. 
54. S.H. Chia, M.R. Homicz, B.L. Schumacher, E.J. Thonar, K. Masuda, R.L. Sah, D. Watson. J. Am. Coll. Surg. 200 (2005) 691-704.

55. Y.J. Lin, C.N. Yen, Y.C. Hu, Y.C. Wu, C.J. Liao, I.M. Chu. J. Biomed. Mater. Res. A 88 (2009) 23-33.

56. A.T. Mehlhorn, H. Schmal, S. Kaiser, G. Lepski, G. Finkenzeller, G.B. Stark, N.P. Sudkamp. Tissue Eng. 12 (2006) 1393-1403.

57. J. Xu, W. Wang, M. Ludeman, K. Cheng, T. Hayami, J.C. Lotz, S. Kapila. Tissue Eng. Part A 14 (2008) 667-680.

58. E.J. Dobratz, S.W. Kim, A. Voglewede, S.S. Park. Arch. Facial Plast. Surg. 11 (2009) 40-47.

59. G.R. Ragetly, G.J. Slavik, B.T. Cunningham, D.J. Schaeffer, D.J. Griffon. J. Biomed. Mater. Res. A 93 (2010) 46-55.

60. D.J. Griffon, M.R. Sedighi, D.V. Schaeffer, J.A. Eurell, A.L. Johnson. Acta Biomater. 2 (2006) 313-320.

61. D.Z. Cai, C. Zeng, D.P. Quan, L.S. Bu, K. Wang, H.D. Lu, X.F. Li. Chin. Med. J. (Engl.) 120 (2007) 197-203.

62. K.E. Yates, F. Allemann, J. Glowacki. Cell Tissue Bank. 6 (2005) 45-54.

63. L. Zheng, H.S. Fan, J. Sun, X.N. Chen, G. Wang, L. Zhang, Y.J. Fan, X.D. Zhang, J. Biomed. Mater. Res. A 93 (2010) 783-792.

64. W. Dai, N. Kawazoe, X. Lin, J. Dong, G. Chen, Biomaterials 31 (2010) 2141-2152.

65. M.K. Kim, S.W. Choi, S.R. Kim, I.S. Oh, M.H. Won, Knee Surg. Sports Traumatol. Arthrosc. 18 (2010) 528-534.

66. A. Pavesio, G. Abatangelo, A. Borrione, D. Brocchetta, A.P. Hollander, E. Kon, F. Torasso, S. Zanasi, M. Marcacci, Novartis Found. Symp. 249 (2003) 203-217; discussion 229-233, 234-208, 239-241.

67. C. Chung, J.A. Burdick, Tissue Eng. Part A 15 (2009) 243-254.

68. D.A. Grande, C. Halberstadt, G. Naughton, R. Schwartz, R. Manji, J. Biomed. Mater. Res. 34 (1997) 211-220.

69. C.H. Baek, Y.J. Ko, Laryngoscope 116 (2006) 1829-1834.

70. S.W. Kang, O. Jeon, B.S. Kim, Tissue Eng. 11 (2005) 438-447.

71. K. Uematsu, K. Hattori, Y. Ishimoto, J. Yamauchi, T. Habata, Y. Takakura, H. Ohgushi, T. Fukuchi, M. Sato, Biomaterials 26 (2005) 4273-4279.

72. J. Zwingmann, A.T. Mehlhorn, N. Sudkamp, B. Stark, M. Dauner, H. Schmal, Tissue Eng. 13 (2007) 2335-2343.

73. H.J. Kim, J.H. Lee, G.I. Im, J. Biomed. Mater. Res. A 92 (2010) 659-666.

74. W.J. Li, R. Tuli, X. Huang, P. Laquerriere, R.S. Tuan, Biomaterials 26 (2005) 5158-5166.

75. C.N. Salinas, K.S. Anseth, Biomaterials 29 (2008) 2370-2377.

76. G.D. Nicodemus, I. Villanueva, S.J. Bryant, J. Biomed. Mater. Res. A 83 (2007) 323-331.

77. L. Zhu, Y. Wu, H. Jiang, W. Liu, Y. Cao, G. Zhou, Br. J. Oral. Maxillofac. Surg. 48 (2010) 462-465.

78. X.Z. Zhou, V.Y. Leung, Q.R. Dong, K.M. Cheung, D. Chan, W.W. Lu, Int J Artif Organs 31 (2008) 480-489.

79. M. Sha'ban, S.H. Kim, R.B. Idrus, G. Khang, J Orthop Surg Res 3 (2008) 17.

80. H.S. Yoo, E.A. Lee, J.J. Yoon, T.G. Park, Biomaterials 26 (2005) 1925-1933.

81. S.C. Wu, J.K. Chang, C.K. Wang, G.J. Wang, M.L. Ho, Biomaterials 31 (2010) 631-640. 
82. A.A. Worster, B.D. Brower-Toland, L.A. Fortier, S.J. Bent, J. Williams, A.J. Nixon, J Orthop. Res. 19 (2001) 738-749.

83. A. Yamaguchi, Semin Cell. Biol. 6 (1995) 165-173.

84. A.C. Akman, R. Seda Tigli, M. Gumusderelioglu, R.M. Nohutcu, Artif. Organs 34 (2010) 65-74.

85. J.M. Brunger, N.P. Huynh, C.M. Guenther, P. Perez-Pinera, F.T. Moutos, J. Sanchez-Adams, C.A. Gersbach, F. Guilak, Proc. Natl. Acad. Sci. U.S.A. 111 (2014) E798-806.

86. G.A. Whitney, H. Mera, M. Weidenbecher, A. Awadallah, J.M. Mansour, J.E. Dennis. Biores. Open Access 1 (2012) 157-165.

87. J.M. Brenner, M. Kunz, M.Y. Tse, A. Winterborn, D.D. Bardana, S.C. Pang, S.D. Waldman. Biotechnol. Prog. 29 (2013) 213-221.

88. L.E. Freed, I. Martin, G. Vunjak-Novakovic. Clin. Orthop. Relat. Res. (1999) S4658.

89. L.E. Freed, G. Vunjak-Novakovic, R. Langer. J. Cell Biochem. 51 (1993) 257-264.

90. B.Y. Bouchet, M. Colon, A. Polotsky, A.H. Shikani, D.S. Hungerford, C.G. Frondoza. J. Biomed. Mater. Res. 52 (2000) 716-724.

91. A.N. Brown, B.S. Kim, E. Alsberg, D.J. Mooney. Tissue Eng. 6 (2000) 297-305.

92. M. Stading, R. Langer. Tissue Eng. 5 (1999) 241-250.

93. G. Vunjak-Novakovic, I. Martin, B. Obradovic, S. Treppo, A.J. Grodzinsky, R. Langer, L.E. Freed. J. Orthop. Res. 17 (1999) 130-138.

94. R.H. Das, G.J. van Osch, M. Kreukniet, J. Oostra, H. Weinans, H. Jahr. J. Orthop. Res. 28 (2010) 537-545.

95. S. Saini, T.M. Wick. Tissue Eng. 10 (2004) 825-832.

96. M.S. Reuther, K.K. Briggs, M.K. Neuman, K. Masuda, R.L. Sah, D. Watson. Otolaryngol. Head Neck Surg. 148 (2013) 753-757.

97. B.D. Elder, K.A. Athanasiou. Osteoarthritis Cartilage 17 (2009) 114-123.

98. S.E. Francioli, I. Martin, C.P. Sie, R. Hagg, R. Tommasini, C. Candrian, M. Heberer, A. Barbero. Tissue Eng. 13 (2007) 1227-1234.

99. R.G. Rosa, P.P. Joazeiro, J. Bianco, M. Kunz, J.F. Weber, S.D. Waldman. PLoS One 9 (2014) e105170.

100. P. Wang, F. Zhu, N.H. Lee, K. Konstantopoulos. J. Biol. Chem. 285 (2010) 24793-24804.

101. B. Pingguan-Murphy, I. Nawi. Clinics (Sao Paulo) 67 (2012) 939-944.

102. C.J. Hunter, J.K. Mouw, M.E. Levenston. Osteoarthritis Cartilage 12 (2004) 117-130.

103. R.M. Schulz, A. Bader. Eur. Biophys. J. 36 (2007) 539-568.

104. A.S. Curtis, N. Gadegaard, M.J. Dalby, M.O. Riehle, C.D. Wilkinson, G. Aitchison. IEEE Trans Nanobioscience 3 (2004) 61-65.

105. M.J. Dalby, M.O. Riehle, D.S. Sutherland, H. Agheli, A.S. Curtis. Eur. J. Cell. Biol. 83 (2004) 159-169.

106. B.K. Teo, S.T. Wong, C.K. Lim, T.Y. Kung, C.H. Yap, Y. Ramagopal, L.H. Romer, E.K. Yim. ACS Nano 7 (2013) 4785-4798.

107. G. Balasundaram, D.M. Storey, T.J. Webster. Int. J. Nanomedicine 9 (2014) 1845-1853.

108. G.E. Park, M.A. Pattison, K. Park, T.J. Webster. Biomaterials 26 (2005) 3075-3082.

109. M.E. Casper, J.S. Fitzsimmons, J.J. Stone, A.O. Meza, Y. Huang, T.J. Ruesink, S.W. O'Driscoll, G.G. Reinholz. Osteoarthritis Cartilage 18 (2010) 981-991. 
110. K.G. Turner, N. Ahmed, J.P. Santerre, R.A. Kandel. Spine J. 14 (2014) 424-434.

111. L. He, B. Liu, G. Xipeng, G. Xie, S. Liao, D. Quan, D. Cai, J. Lu, S. Ramakrishna. Eur. Cell. Mater. 18 (2009) 63-74.

112. J.P. Chen, C.H. Su. Acta Biomater. 7 (2011) 234-243.

113. C. Spadaccio, A. Rainer, M. Trombetta, G. Vadala, M. Chello, E. Covino, V. Denaro, Y. Toyoda, J.A. Genovese. Ann. Biomed. Eng. 37 (2009) 1376-1389.

114. Y. Pan, D. Xiong, F. Gao. J. Mater. Sci. Mater. Med. 19 (2008) 1963-1969.

115. S.H. Hsu, H.J. Yen, C.L. Tsai. Artif. Organs 31 (2007) 854-868.

116. S. Kay, A. Thapa, K.M. Haberstroh, T.J. Webster. Tissue Eng. 8 (2002) 753-761.

117. L.A. MacGinitie, Y.A. Gluzband, A.J. Grodzinsky. J. Orthop. Res. 12 (1994) 151-160.

118. W. Wang, Z. Wang, G. Zhang, C.C. Clark, C.T. Brighton. Clin. Orthop. Relat. Res. (2004) S163-173.

119. D. Khang, G.E. Park, T.J. Webster. J. Biomed. Mater. Res. A 86 (2008) 253-260.

120. R.A. MacDonald, B.F. Laurenzi, G. Viswanathan, P.M. Ajayan, J.P. Stegemann. J. Biomed. Mater. Res. A 74 (2005) 489-496.

121. S.M. Lim, S.H. Oh, H.H. Lee, S.H. Yuk, G.I. Im, J.H. Lee. J. Mater. Sci. Mater. Med. 21 (2010) 2593-2600.

122. D.C. Surrao, J.W. Hayami, S.D. Waldman, B.G. Amsden. Biomacromolecules 11 (2010) 3624-3629.

123. S.D. Waldman, C.G. Spiteri, M.D. Grynpas, R.M. Pilliar, R.A. Kandel. J. Orthop. Res. 21 (2003) 590-596. 
Chapter 16

452 